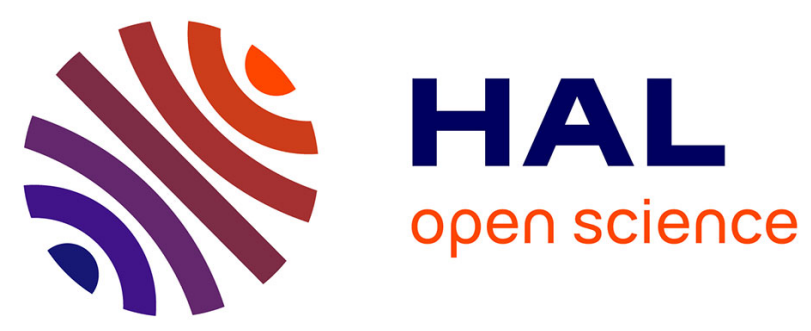

\title{
Spot fires: fuel bed flammability and capability of firebrands to ignite fuel beds
}

\author{
A. Ganteaume, C. Lampin-Maillet, M. Guijarro, C. Hernando, M. Jappiot, T. \\ Fonturbel, P. Perez-Gorostiaga, J.A. Vega
}

\section{> To cite this version:}

A. Ganteaume, C. Lampin-Maillet, M. Guijarro, C. Hernando, M. Jappiot, et al.. Spot fires: fuel bed flammability and capability of firebrands to ignite fuel beds. International Journal of Wildland Fire, 2009, 18, 18 p. 10.1071/WF07111 . hal-00457608

\section{HAL Id: hal-00457608 \\ https://hal.science/hal-00457608}

Submitted on 17 Feb 2010

HAL is a multi-disciplinary open access archive for the deposit and dissemination of scientific research documents, whether they are published or not. The documents may come from teaching and research institutions in France or abroad, or from public or private research centers.
L'archive ouverte pluridisciplinaire HAL, est destinée au dépôt et à la diffusion de documents scientifiques de niveau recherche, publiés ou non, émanant des établissements d'enseignement et de recherche français ou étrangers, des laboratoires publics ou privés. 
Spot fires: Fuel bed flammability and ignition capability of firebrands

Anne Ganteaume ${ }^{A}$; ; Corinne Lampin-Maillet ${ }^{A}$, Mercedes Guijarro $^{B}$, Carmen Hernando ${ }^{B}$, Marielle Jappiot ${ }^{A}$; Teresa Fonturbel ${ }^{C}$, Pedro Pérez-Gorostiaga ${ }^{C}$ and José A. Vega ${ }^{C}$

A: Cemagref UR EMAX, 3275 Route de Cézanne, CS 40061, 13182 Aix-en-Provence, France

B: Centro de Investigación Forestal, Instituto Nacional de Investigación y Tecnología Agraria y Alimentaria,

C: Departamento de Protección Ambiental, Centro de Investigación e Información Ambiental de Lourizán, PO

Box 127, 36080 Pontevedra, Spain

13 Brief summary: The capacity of several fuel beds to be ignited by firebrands and to sustain a fire was assessed 14 through the study of their flammability. Then, the capability of different types of firebrands to ignite fuel beds was studied through laboratory tests, in order to know their behaviour when they are involved in spot fires. 


\section{Spot fires: Fuel bed flammability and capability of firebrands to ignite fuel beds}

17

Anne Ganteaume ${ }^{A}{ }^{\mathrm{D}}$; Corinne Lampin-Maillet ${ }^{A}$, Mercedes $_{\text {Guijarro }}{ }^{B}$, Carmen Hernando $^{B}$, Marielle Jappiot $^{A}$; Teresa Fonturbel ${ }^{C}$, Pedro Pérez-Gorostiaga ${ }^{C}$ and José A. Vega ${ }^{C}$

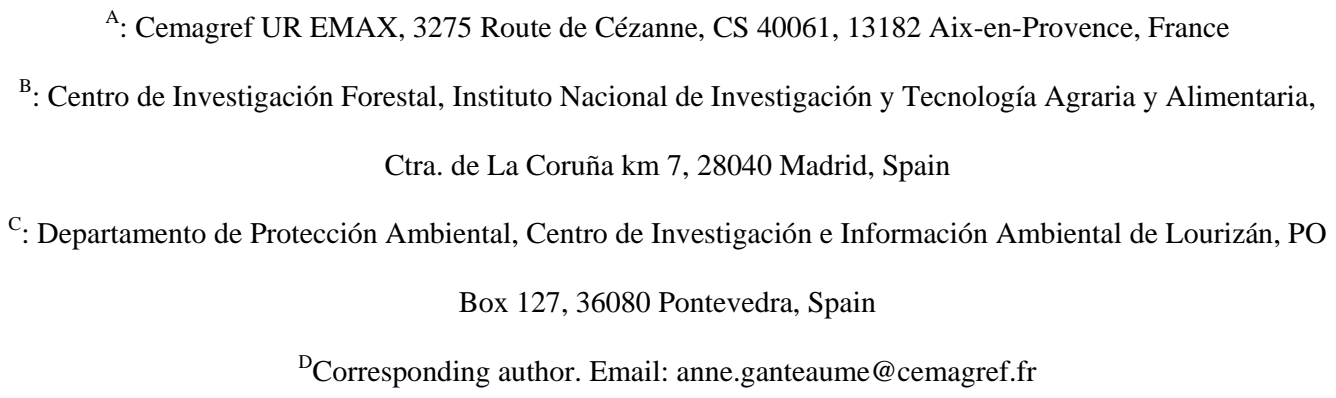
time-to-ignition, and a decrease of the other flammability parameters. The capability of firebrands to ignite fuel beds is higher when the firebrands drop in flaming phase and with no air flow than in glowing phase with air flow. Logistic regression models to predict fuel bed ignition probability were developed. As a whole, results show a relationship between ignition probability of fuel bed and type or weight of firebrands. Pinus pinaster cone scale, Pinus halepensis cone scale, Eucalyptus globulus leaf and bark can have ignition probabilities at least twice higher than bark of Pines when fallen in flaming combustion.

Additional keywords: ember, wildfire, spotting, ignition probability, flammability 
Fire spotting, with production of flaming or glowing particles transported downwind, may cause secondary wildfires, ahead the main front. Therefore, fire prevention and fire fighting strategies must take into account this phenomenon. Both ember transport and landscape scale fire models are well detailed in the literature (e.g. Tarifa et al. 1965; Albini 1979, 1981, 1983; Rothermel 1983; Finney 1998; Gardner et al. 1999; Hargrove et al. 2000), but other aspects of fire spread by spotting remain less known such as the ignitibility of fuel beds by point source or the capability of firebrands to ignite fuel beds. The characteristics (species, moisture content, density, etc.) of the fuel that receives the brand and the vegetation that is the source of firebrands may influence the occurrence of a spot fire. Several laboratory studies of fire spread in different types of fuel bed used a line ignition and pine litter (Rothermel and Anderson 1966; Delaveaud 1981; Ventura et al. 1988; Viegas and Neto 1990; Vega et al. 1993; Valette et al. 1994; Mendes-Lopes et al. 1998; Guijarro and Hernando 2000). Although this kind of ignition is appropriate for fire spread studies, it does not provide any information for fire spotting in which the ignition occurs from a point source. Blackmarr (1972) and Ferreira (1988) experimented with point source ignitions using dropped lit matches. Recently, Manzello et al. (2006a, 2006b and 2006c) investigated the ignition of fuel beds found in the wildland-urban interface areas, using an apparatus that allowed the ignition and deposition of single or multiple firebrands. Some authors (Blackmarr 1972; Ferreira 1988; Viney and Hatton 1989; Frandsen 1997; Lin 1999; Hargrove et al. 2000; Plucinski and Anderson 2008) have also investigated the ignition probability of fuel beds in relation with their characteristics, but they did not take into account firebrand characteristics. Nevertheless, it is important to carry out fire studies using commonly found firebrands that cause spot fires and to develop a prediction of the capability of different firebrands to ignite fuel beds as a function of brands and fuel beds characteristics. In this framework, one of the objectives of the present work is to assess the capacity of several fuel beds to be ignited by firebrands and to sustain a fire, through the study of their flammability (Fuel beds tests). The other objective is to assess the capability of different types of firebrands to ignite fuel beds (Firebrands tests) analyzing the ignition probability of the firebrands as a function of physical variables of firebrands and fuel beds. 
74

Tests of the flammability of fuel beds and the capability of firebrands to ignite fuel beds were conducted under laboratory conditions by three Research Teams (INIA and CINAM in Spain; Cemagref in France), following similar methodologies for testing the most common species from each study region: Central and North-Western Spain, and South France, respectively.

Fuel beds tests

The fuel beds selected for this study were litters of Arbutus unedo L., Eucalyptus globulus L., Pinus halepensis Mill., Pinus pinaster Ait., Pinus pinea L., Quercus faginea Lam. 1783, Quercus pubescens Willd, Ulex europaeus L. and two different types of cured grasses with different depth and density. These fuel beds are representative of receptive fuels on which fire spotting has been observed in field studies (SALTUS 2001). The litters were collected in pure stands of each of these coniferous (Pinus halepensis, P. pinaster and P. pinea) and hardwood trees (Eucalyptus globulus, Quercus faginea and Q. pubescens). Whereas coniferous and hardwood litters were composed of needles or leaves, respectively, fuel beds of Ulex europaeus were made of fine ground stems. This last type of fuel bed usually results from the grinding of plant debris following the clearing of Ulex, this process is frequently used as sylvicultural treatment in Galicia (NW of Spain). Grasses were collected as turfs from the ground in order not to alter their structure.

For each type of fuel beds, the effect of both bulk density (BD in $\mathrm{kg} \mathrm{m}^{-3}$ ) and fuel moisture content (FMC, in percentage) were analysed. To determine the bulk density as the fuel load divided by the depth, average depth of each fuel bed was estimated through six measurements at different points of the fuel. In the case of grasses, average depth was obtained following the guidelines of Burgan and Rothermel (1984), as 43\% of the maximum stalk height. To obtain a relatively wide range of moisture values, the material of fuel beds was conditioned in climatic chamber, air dried or oven dried. Table 1 summarizes the characteristics of the tested fuel beds. As a whole, the fuel load varies from 0.49 (Pinus pinea and Quercus faginea litter) to $1.80 \mathrm{~kg} \mathrm{~m}^{-2}$ (P. halepensis litter) between woody species, whereas it varies from 0.09 to $0.25 \mathrm{~kg} \mathrm{~m}^{-2}$ in grasses. The moisture content values for the woody species range from $0.48 \%$ (Pinus pinaster) to $22.89 \%$ (Ulex europaeus), while they range from 9.60 to $49.90 \%$ in the case of grasses. FMC values of Arbutus unedo and P. halepensis are less than 
10\%. The bulk density values for woody species range from 9.06 (P. pinea) to $72.43 \mathrm{~kg} \mathrm{~m}^{-3}$ (Eucalyptus globulus), while they range from 0.79 to $3.56 \mathrm{~kg} \mathrm{~m}^{-3}$ for the grasses.

Flammability of the fuel beds has been analyzed, according to the definitions given by Anderson (1970) and Martin et al. (1994), as the result of the following four phenomena: ignitability (the amount of time until ignition once a material is exposed to a known ignition source), sustainability (how will the fuel continues to burn), combustibility (how rapidly or intensely a material burns), and consumability (quantity of material that is consumed). Therefore, fuel bed flammability has been evaluated taking into account the time required until the flame appears on the fuel bed, the rate of fire spread, the rate of combustion and the fuel consumption ratio.

The experimental burnings were conducted in fire benches, on which the different fuel beds were laid,

111 forming either square fuel layers of $0.70 \mathrm{~m} \times 0.70 \mathrm{~m}$ (Figure 1) or round layers with a diameter of $0.70 \mathrm{~m}$. The

112 fire benches were placed on a scale (sensitivity to $1 \mathrm{~g}$ ), connected to a computer, enabling a continuous register

113 of the weight loss during the combustion of the fuel bed. A scale, in $\mathrm{cm}$, which enabled visual assessment of the

114 flame height during the tests, was placed on one side of the bench. In order to ensure that the ignition of the fuel

115 bed occurred under similar conditions, "standard firebrands" were used. These were cubes $(2 \mathrm{~cm}$ x $2 \mathrm{~cm} \times 1 \mathrm{~cm})$

116 of Pinus sylvestris wood (FMC = 12\%), ignited using an electric radiator (Standard NF P 92-509-1985) (Figure

117 1). Once the ignition occurred, the flaming firebrand was placed in the centre of the fuel layer and the 118 chronometer was connected. The decrease of the fuel bed weight was then recorded as well as the parameters 119 characterizing the flammability of the fuel beds : (1) time-to-ignition of the fuel bed (TIB, in s) calculated as 120 from the moment the firebrand was placed on the fuel bed, (2) rate of fire spread (RoS, in $\left.\mathrm{cm} \mathrm{s}^{-1}\right)$ obtained from 121 the mean value of the time required by the fire to reach the four edges of the fuel layer, (3) rate of fuel bed 122 combustion (RoC, in $\mathrm{g} \mathrm{s}^{-1}$ ) calculated as the weight consumed during the flaming combustion divided by the 123 duration of the flaming combustion, (4) maximum and mean flame height (FH and MFH, in $\mathrm{cm}$ ), (5) fuel

124 consumption ratio (FCR) calculated as the ratio of the weight consumed by combustion and the initial fuel weight. 
Table 1. Fuel load, fuel moisture content (FMC) and bulk density of the studied fuel beds

Mean, standard deviation, minimum and maximum values, FMC: fuel moisture content, $\mathrm{n}=$ number of tests

\begin{tabular}{|c|c|c|c|c|}
\hline Fuel bed & $\mathbf{n}$ & Fuel load $\left(\mathrm{kg} \mathrm{m}^{-2}\right)$ & FMC (\%) & Bulk density $\left(\mathrm{kg} \mathrm{m}^{-3}\right)$ \\
\hline Arbutus unedo litter & & $1.37(0.01)$ & $\mathbf{3 . 5 9}(2.76)$ & $45.73(0.46)$ \\
\hline (S France) & 87 & $(1.36-1.40)$ & $(1.00-8.23)$ & $(45.45-46.63)$ \\
\hline Eucalyptus glolubus litter & & $\mathbf{1 . 0 1}(0.09)$ & $\mathbf{7 . 8 9}(4.22)$ & $35.72(11.49)$ \\
\hline (NW Spain) & 68 & $(0.84-1.19)$ & $(1.11-17.53)$ & $(15.79-72.43)$ \\
\hline Pinus halepensis litter & & $1.39(0.38)$ & $3.91(3.09)$ & $\mathbf{4 6 . 5 0}(12.53)$ \\
\hline (S France) & 67 & $(1.03-1.80)$ & $(1.00-8.89)$ & $(34.29-60.57)$ \\
\hline Pinus pinaster litter & & $1.04(0.08)$ & $7.77(5.02)$ & 36.62 (13.05) \\
\hline (NW Spain) & 56 & $(0.87-1.23)$ & $(0.48-19.83)$ & $(20.11-70.78)$ \\
\hline Pinus pinea litter & & $\mathbf{0 . 5 2}(0.02)$ & $9.27(3.36)$ & $14.68(4.92)$ \\
\hline (Central Spain) & 36 & $(0.49-0.55)$ & $(2.50-14.50)$ & $(9.06-25.12)$ \\
\hline Quercus faginea litter & & $\mathbf{0 . 5 2}(0.02)$ & $9.77(3.23)$ & $20.10(6.02)$ \\
\hline (Central Spain) & 44 & $(0.49-0.55)$ & $(3.60-15.20)$ & $(15.40-44.82)$ \\
\hline Quercus pubescens litter & & $\mathbf{0 . 9 5}(0.01)$ & $\mathbf{6 . 0 2}(4.11)$ & $20.49(7.52)$ \\
\hline (S France) & 128 & $(0.91-0.99)$ & $(1.00-14.28)$ & $(15.15-32.99)$ \\
\hline Ulex europaeus litter & & $\mathbf{0 . 9 8}(0.09)$ & $9.20(7.33)$ & $19.96(7.37)$ \\
\hline (NW Spain) & 29 & $(0.84-1.13)$ & $(0.77-22.89)$ & $(11.22-34.63)$ \\
\hline
\end{tabular}




\begin{tabular}{ccccc}
\hline Grasses type 1 & & $\mathbf{0 . 2 3}(0.02)$ & $\mathbf{2 1 . 2 1}(12.36)$ & $\mathbf{1 . 7 8}(0.76)$. \\
(Central Spain) & 10 & $(0.19-0.25)$ & $(9.90-43.40)$ & $(0.92-3.56)$ \\
\hline Grasses type 2 & & $\mathbf{0 . 1 2}(0.01)$ & $\mathbf{1 5 . 8 1}(9.83)$ & $(0.79-2.61)$ \\
(Central Spain) & 16 & $(0.09-0.13)$ & $(0.47)$ & $\mathbf{1 . 3 4}$ \\
\hline
\end{tabular}




\section{Firebrands tests}

The study was carried out in different conditions of i) fuel beds, ii) air flows, at different speeds $(0,0.8,2.5$ and $4.5 \mathrm{~m} \mathrm{~s}^{-1}$ ) with different directions (horizontal and oblique $45{ }^{\circ} \mathrm{C}^{1}$ ), iii) firebrand states and (iv) firebrand types.

Table 2 lists these studied key variables.

Table 2. Experimental conditions of the firebrand tests

\begin{tabular}{|c|c|c|c|}
\hline Fuel beds & Air flow & Firebrand state & Firebrand type \\
\hline Pinus halepensis & None & Flaming (on air- & Pinus halepensis twigs, bark \\
\hline needles & Oblique (2.5 and $\left.4.5 \mathrm{~m} \mathrm{~s}^{-1}\right)$ & dried needles & and cone scales, Quercus ilex \\
\hline (air-dried and oven- & & only) & leaves, Quercus suber bark \\
\hline dried) & & Glowing & \\
\hline \multirow{4}{*}{$\begin{array}{l}\text { Pinus pinea needles } \\
\text { Cured grasses }^{2}\end{array}$} & None & Flaming & Pinus pinea twigs, bark and \\
\hline & & & cone scales, Quercus ilex \\
\hline & Horizontal and oblique $\left(0.8 \mathrm{~m} \mathrm{~s}^{-1}\right)$ & Glowing & leaves and acorn, Pinus \\
\hline & & & halepensis cone \\
\hline Pinus pinaster needles & None & Flaming & Pinus pinaster, Pinus radiata \\
\hline Eucalyptus globulus & & & and Eucalyptus globulus bark, \\
\hline \multirow[t]{2}{*}{ leaves } & Horizontal and oblique $\left(0.8 \mathrm{~m} \mathrm{~s}^{-1}\right)$ & Glowing & E. globulus leaves, $P$. pinaster \\
\hline & & & cone scales \\
\hline
\end{tabular}

\footnotetext{
${ }^{1}$ An oblique air flow of about $45^{\circ}$ to the tray holding the fuel bed was selected because it was the minimum angle avoiding the air flow to blow off the fuel particles from the aluminium tray. A later modification of the experimental device allowed conducting tests with a horizontal air flow.

${ }^{2}$ To construct grass fuel beds in the firebrand study, cured grasses were collected cutting them at the base of the stalks. Fuel beds were constructed lying horizontally $5 \mathrm{~g}$ of stalks in the aluminium tray of the experimental device (Fig. 2), in such a way that their bulk density was $4.63 \mathrm{~kg} \mathrm{~m}^{-3}$.
} 
Concerning fuel beds moisture content, two different levels of FMC were tested in Pinus halepensis needles beds: air-dried $(\mathrm{FMC}=3.9 \%)$ and oven-dried 48 hours at $60^{\circ} \mathrm{C}(\mathrm{FMC}=0 \%)$. Pinus pinea needles beds and cured grasses fuel beds were conditioned in a chamber at $22{ }^{\circ} \mathrm{C}$ and $60 \%$ relative humidity, in such a way that the FMC were $11.19 \pm 0.50 \%$ and $9.20 \pm 1.45 \%$, respectively. Pinus pinaster needles bed and Eucalyptus globulus leaves beds FMC were $3.17 \pm 2.08 \%$ and $3.16 \pm 1.47 \%$, respectively.

The two states of firebrands (flaming and glowing) represent the possible states that occur at the moment of contact between the brand and the fuel. Some authors (Tarifa et al. 1967; Waterman and Takata 1969) have stated that when the firebrands contact ignitable fuel beds, they are most likely in a state of glowing combustion, but Babrauskas (2003) has confirmed that it was possible for firebrands to remain in a flaming state under an air flow and therefore it is reasonable to assume that some firebrands may still be flaming upon impact. Thus, the ignition capability of the firebrands was assessed on both flaming and glowing phases. Each type of firebrand was tested only on the fuel bed on which they are naturally combined in their respective ecosystem. Before the tests, the firebrands were weighed and measured in length, width and thickness. For all of them, according to their form (cylinder, rectangle, and sphere), the surface of contact $\left(\mathrm{cm}^{2}\right)$ with the fuel bed (laid on their biggest face), the total surface $\left(\mathrm{cm}^{2}\right)$, the volume $\left(\mathrm{cm}^{3}\right)$ and the total surface-to-volume ratio were calculated. The firebrands were oven-dried $24 \mathrm{~h}$ at $30{ }^{\circ} \mathrm{C}$ until reaching a constant weight. For each type of firebrands, the moisture content was determined before starting each experiment and is assumed to be constant for each experiment. Table 3 presents the characteristics of the tested firebrands.

The firebrands (40 for each type) were ignited on an electric radiator, and then dropped on the fuel bed contained in an aluminium tray $(22 \mathrm{~cm} \times 16 \mathrm{~cm} \times 4.5 \mathrm{~cm})$ (Figure 2). The air flow was provided by a domestic fan, located at sufficient distance from the fuel bed to generate different speeds.

Once the selected firebrands on the radiator, they were left until they ignited or until they glowed, depending on the selected state, before being used for the fuel bed ignition. Once the flaming or glowing firebrands were dropped on the fuel bed, the elapsed time until the occurrence of the ignition (TIB, time-toignition of the fuel bed) and the ignition frequency (IFB) of the fuel bed were recorded. For the glowing firebrands, the fan was started as soon as they were dropped on the fuel bed. 
Table 3. Weight, surface of contact, total surface, volume, surface-to-volume ratio and fuel moisture content (FMC) of the studied firebrands

Mean, standard deviation, minimum and maximum values

\begin{tabular}{|c|c|c|c|c|c|c|c|}
\hline Type of & firebrand & Weight (g) & Surface of contact $\left(\mathrm{cm}^{2}\right)$ & Total surface $\left(\mathrm{cm}^{2}\right)$ & Volume $\left(\mathrm{cm}^{3}\right)$ & Surface to volume ratio $\left(\mathrm{cm}^{-1}\right)$ & FMC ( \\
\hline \multirow[t]{4}{*}{ Twigs } & Pinus halepensis & $\mathbf{0 . 6 7}(0.32)$ & $2.46(0.6)$ & $7.72(1.87)$ & $\mathbf{0 . 9 9}(0.46)$ & $8.74(2.26)$ & 8.13 \\
\hline & $\mathrm{N}=200$ & $(0.14-1.78)$ & $(1.06-4.08)$ & $(3.33-12.80)$ & $(0.17-2.46)$ & $(5.20-18.96)$ & \\
\hline & Pinus pinea & $\mathbf{0 . 3 9}(0.15)$ & $2.39(0.65)$ & $7.50(2.03)$ & $\mathbf{0 . 7 6}(0.39)$ & $11.16(3.00)$ & 8.85 \\
\hline & $\mathrm{N}=240$ & $(0.12-0.85)$ & $(0.90-4.32)$ & $(2.83-13.56)$ & $(0.14-2.31)$ & $(5.000-20.00)$ & \\
\hline \multirow[t]{8}{*}{ Bark plates } & Pinus halepensis & $\mathbf{0 . 4 3}(0.26)$ & $7.29(3.17)$ & $\mathbf{1 4 . 5 9}(6.34)$ & $1.17(0.84)$ & $\mathbf{1 4 . 0 6}(4.29)$ & 9.93 \\
\hline & $\mathrm{N}=200$ & $(0.12-2.16)$ & $(2.00-23.20)$ & $(4.00-46.40)$ & $(0.27-8.64)$ & $(2.50-29.41)$ & \\
\hline & Pinus pinaster & $\mathbf{1 . 0 1}(0.69)$ & $10.35(5.00)$ & $26.88(12.19)$ & $4.57(3.51)$ & $8.24(5.90)$ & 6.16 \\
\hline & $\mathrm{N}=265$ & $(0.20-3.80)$ & $(3.38-29.44)$ & $(8.04-71.80)$ & $(0.19-22.16)$ & $(3.10-42.32)$ & \\
\hline & Pinus pinea & $\mathbf{0 . 6 9}(0.34)$ & $14.02(5.32)$ & $28.05(10.64)$ & $3.38(2.58)$ & $11.19(5.32)$ & 8.85 \\
\hline & $\mathrm{N}=240$ & $(0.16-1.92)$ & $(4.83-33.58)$ & $(9.66-67.16)$ & $(0.59-15.79)$ & $(2.86-20.00)$ & \\
\hline & Pinus radiata & $1.44(1.27)$ & $7.08(3.62)$ & $21.14(11.81)$ & $4.89(5.12)$ & 6.35 (2.96) & 4.44 \\
\hline & $\mathrm{N}=241$ & $(1.30-8.30)$ & $(2.11-24.94)$ & $(6.04-72.85)$ & $(0.38-30.72)$ & $(2.07-21.31)$ & \\
\hline \multirow[t]{2}{*}{ Bark } & Eucalyptus globulus & $\mathbf{0 . 6 6}(0.33)$ & $9.84(3.54)$ & $19.68(7.09)$ & $1.09(0.75)$ & $20.39(5.64)$ & 4.83 \\
\hline & $\mathrm{N}=245$ & $(0.20-2.00)$ & $(2.46-22.80)$ & $(4.92-45.60)$ & $(0.25-6.94)$ & $(3.33-40.00)$ & \\
\hline Leaves & Eucalyptus globulus & $\mathbf{0 . 6 1}(0.17)$ & $25.86(7.21)$ & $\mathbf{5 1 . 7 2}(14.42)$ & $1.31(0.36)$ & $39.52(1.09)$ & 3.59 \\
\hline
\end{tabular}




\begin{tabular}{|c|c|c|c|c|c|c|c|}
\hline & $\mathrm{N}=239$ & $(0.20-1.40)$ & $(8.85-52.29)$ & $(17.70-104.58)$ & $(0.44-2.61)$ & $(37.04-40.00)$ & \\
\hline & Quercus ilex (France) & $\mathbf{0 . 1 2}(0.04)$ & $10.62(3.01)$ & $21.25(6.01)$ & $\mathbf{0 . 3 5}(0.13)$ & $\mathbf{6 4 . 3 1}(14.35)$ & 11.19 \\
\hline & $\mathrm{N}=200$ & $(0.05-0.30)$ & $(4.90-21.70)$ & $(9.80-43.40)$ & $(0.13-1.00)$ & $(24.39-100.00)$ & \\
\hline & Quercus ilex (Spain) & $\mathbf{0 . 1 4}(0.04)$ & $9.27(2.34)$ & $\mathbf{1 8 . 5 5}(4.68)$ & $\mathbf{0 . 4 6}(0.13)$ & $\mathbf{4 0 . 8 5}(6.96)$ & 6.45 \\
\hline & $\mathrm{N}=240$ & $(0.07-0.28)$ & $(3.48-21.09)$ & $(6.96-42.18)$ & $(0.17-1.05)$ & $(28.57-100.00)$ & \\
\hline \multirow[t]{6}{*}{ Cone scales } & Pinus halepensis & $\mathbf{0 . 2 2}(0.04)$ & $2.66(0.52)$ & $4.92(1.19)$ & $\mathbf{0 . 7 0}(0.24)$ & $\mathbf{7 . 7 9}(3.19)$ & 8.77 \\
\hline & $\mathrm{N}=200$ & $(0.13-0.35)$ & $(0.99-4.20)$ & $(2.11-8.15)$ & $(0.33-1.46)$ & $(2.93-18.29)$ & \\
\hline & Pinus pinaster & $\mathbf{0 . 6 5}(0.15)$ & $5.11(2.10)$ & $10.21(4.21)$ & $1.85(0.77)$ & $5.87(2.55)$ & 3.99 \\
\hline & $\mathrm{N}=241$ & $(0.30-1.10)$ & $(0.48-10.21)$ & $(0.96-20.42)$ & $(0.52-4.54)$ & $(0.91-21.28)$ & \\
\hline & Pinus pinea & $1.53(0.44)$ & $9.25(1.61)$ & $18.49(3.21)$ & $\mathbf{6 . 4 3}(1.69)$ & $2.96(0.46)$ & 6.90 \\
\hline & $\mathrm{N}=240$ & $(0.49-3.10)$ & $(4.83-13.72)$ & $(9.66-27.44)$ & $(2.46-12.67)$ & $(1.82-4.00)$ & \\
\hline \multirow[t]{2}{*}{ Cone } & Pinus halepensis & $\mathbf{3 1 . 3 1}(11.24)$ & $48.27(16.53)$ & $157.69(53.57)$ & $194.17(98.55)$ & $\mathbf{0 . 8 9}(0.16)$ & 6.25 \\
\hline & $\mathrm{N}=240$ & $(11.50-69.98)$ & $(17.98-102.18)$ & $(65.01-342.90)$ & $(49.30-597.21)$ & $(0.57-1.32)$ & \\
\hline \multirow[t]{2}{*}{ Acorn } & Quercus ilex & $2.37(0.75)$ & $\mathbf{3 . 9 3}(0.90)$ & $14.54(3.46)$ & $5.32(1.90)$ & $\mathbf{2 . 8 5}(0.34)$ & 6.53 \\
\hline & $\mathrm{N}=240$ & $(0.99-4.20)$ & $(2.30-6.30)$ & $88.04-23.75)$ & $(2.14-10.88)$ & $(2.18-3.75)$ & \\
\hline \multirow[t]{2}{*}{ Bark cube } & Quercus suber & 0.71 (0.26) & $2.04(0.56)$ & $\mathbf{1 0 . 3 7}(2.53)$ & $2.26(0.86)$ & $4.88(1.46)$ & 8.77 \\
\hline & $\mathrm{N}=200$ & $(0.26-2.13)$ & $(0.12-4.46)$ & $(2.84-21.85)$ & $(0.12-6.81)$ & $(3.21-23.67)$ & \\
\hline
\end{tabular}




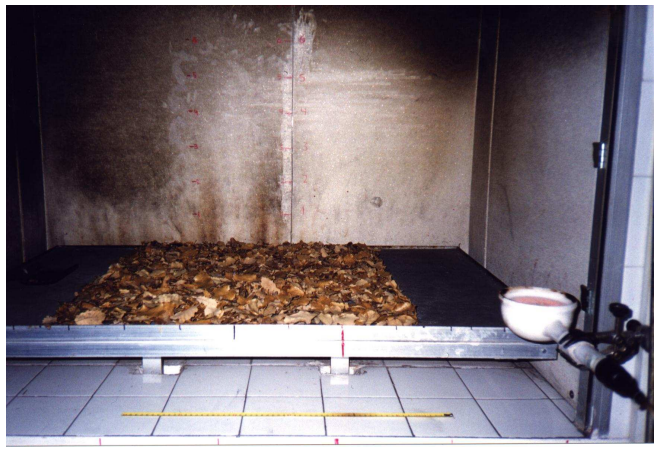

Fig 1. Experimental device used in the fuel beds tests

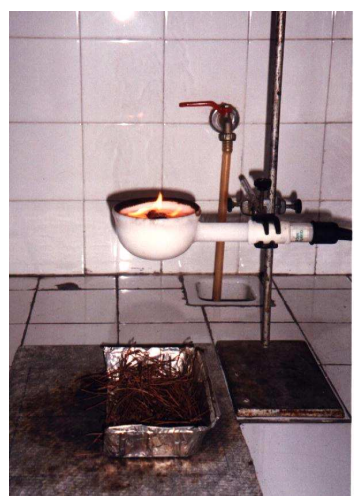

Fig 2. Experimental device used in the firebrands tests

Statistics

Fuel beds tests

The effects of both fuel moisture content (FMC) and bulk density (BD) on the flammability of each fuel bed were analysed using multiple regression models.

A logistic regression was used to predict the ignition probability of the $P$. halepensis, $Q$. pubescens and $A$. unedo litter beds ${ }^{3}$ as a function of their bulk density and FMC. This analysis uses the maximum likelihood estimates to determine independent variable coefficients. The improvement Chi-square tests the hypothesis that the term entered or removed at its step significantly changes the prediction. The goodness of fit Chi-square was used to test the hypothesis that the model adequately fits the data.

The prediction of Rate of Spread (RoS) with fuel moisture content as independent variable was performed using linear regression models. To compare the effect of FMC on each fuel bed, differences between the slopes and the intercepts were analysed for each fuel bed using of the conditional sum of squares of the equations linking RoS, FMC and fuel bed. One factor parametric ANOVA (Kruskal-Wallis Test) was used to validate the significance of the relationship between the type of fuel beds and the fuel bed flammability parameters (TIB, RoS, RoC, FH, MFH, FCR) measured in the experiment.

\footnotetext{
${ }^{3}$ Bulk density not varying within a same type of fuel bed, it was not possible to carry out a logistic regression analysis of the ignition probability for each type of fuel bed. Thus, the various litter beds were merged to solve this problem.
} 


\section{Firebrands tests}

A logistic regression analysis was used to model the probability of the firebrands to ignite fuel beds as a function of physical variables of firebrands and fuel beds. This analysis allows the relationship between dependent and independent variables to be determined and to predict the ignition probability of a single case, classifying individuals within the group with the character or without it, as a function of its probability. Logistic regression uses the maximum likelihood estimate to determine independent variables coefficients. The log of the likelihood gives a measure of the goodness of fit for the model. A high reduction of the log likelihood at each step means the model fits the data more adequately. Consequently, a low final value of that parameter indicates a good fit. The improvement chi-square tests the hypothesis that the term entered or removed at each step significantly changes the prediction. The goodness of fit chi-square was used to test the hypothesis that the model fits the data adequately. The Hosmer-Lemeshow test was used to compare the observed and predicted frequencies. In this study the dependent variable was the ignition probability of the fuel bed when a firebrand dropped on it. Two different types of independent variables were considered: qualitative (firebrand type, fuel bed type and air flow type), quantitative (for the firebrand: weight, fuel moisture content, surface of contact with the fuel bed, volume and for the fuel bed: moisture content and bulk density).

One factor parametric ANOVA (Kruskal-Wallis Test) was used to analyze the significance of the relationship between the parameters air flow, fuel bed types, firebrand types and the fuel bed ignition frequency and time to ignition. The comparison of means, using the Mann-Whitney non parametric test, was performed in order to test the significance of the air flow characteristics (speed and direction) and the fuel moisture content on the ignition frequency and the time to ignition of the different firebrands laid of the different fuel beds.

\section{Results and discussion}

Fuel beds tests

Flammability parameters 
Table 4 shows the flammability parameters recorded for each fuel bed. The statistical tests (Kruskal-Wallis) show that the fuel bed type has a significant effect on the recorded parameters $(\mathrm{KW}<100$ for RoC and FCR, KW $>100$ for TIB, RoS, FH, MFH; p=0.000). The Grasses type 1 have the highest values of RoS, RoC, FH, FCR and the lowest values of TIB, as well as a $100 \%$ ignition frequency, being therefore the most flammable fuel bed. On the contrary, the least flammable one is A. unedo litter which has the highest value of TIB and the lowest values of other parameters. The species belonging to the genus Pinus, as well as Ulex europaeus show higher values of ignition frequency (between 89 and $100 \%$ ), rates of spread and combustion, flame heights and lower time-to-ignition than other fuel beds. The species belonging to the genus Quercus reach higher time-toignition than Pinus fuel beds, but lower values of the other parameters, being therefore these Quercus fuel beds less flammable than the studied Pinus ones. Eucalyptus globulus litter has high values of ignition frequency and flame height, along with relatively high values of time to ignition and low rate of spread. These results agree with Trabaud (1976), who reported that the essential oils and terpenes contained in the fuel (as is the case of Eucalyptus litter) enhance the flame height more than the time to ignition. Grasses present the lowest time-toignition and the highest rate of spread and rate of combustion, as well as the highest flames, thus revealing their higher flammability compared to the litters, despite the higher fuel moisture values in grasses than in litters. 


\section{Table 4. Parameters of fuel bed flammability}

Mean, standard deviation, minimum and maximum values; --: non measured parameter; n: number of tests in which ignition occurred, IFB: ignition frequency, TIB: time-to-ignition, RoS: rate of fire spread, RoC: rate of fuel bed combustion, FH and MFH: maximum and mean flame height, FCR: fuel consumption ratio

\begin{tabular}{|c|c|c|c|c|c|c|c|c|}
\hline Fuel bed & $\mathbf{n}$ & IFB (\%) & TIB (s) & $\operatorname{RoS}\left(\mathrm{cm} \mathrm{s}^{-1}\right)$ & $\operatorname{RoC}\left(\mathrm{g} \mathrm{s}^{-1}\right)$ & FH (cm) & MFH (cm) & FCR (\%) \\
\hline Arbutus unedo litter & 57 & 65 & $\begin{array}{l}11.92(13.21) \\
(1.75-52.50)\end{array}$ & $\begin{array}{c}\mathbf{0 . 0 9}(0.03) \\
(0.04-0.15)\end{array}$ & $\begin{array}{c}\mathbf{0 . 6 9}(0.22) \\
(0.24-1.14)\end{array}$ & -- & -- & -- \\
\hline Eucalyptus glolubus litter & 64 & 94 & $\begin{array}{c}\mathbf{9 . 0 9}(7.97) \\
(2.00-58.95)\end{array}$ & $\begin{array}{c}\mathbf{0 . 1 7}(0.06) \\
(0.05-0.30)\end{array}$ & -- & $\begin{array}{c}\mathbf{7 4 . 1 0}(22.38) \\
(30.00-110.00)\end{array}$ & $\begin{array}{c}\mathbf{6 5 . 0 8}(23.29) \\
(24.00-110.00)\end{array}$ & $\begin{array}{c}\mathbf{8 8 . 1 3}(12.53) \\
(63.06-94.80)\end{array}$ \\
\hline Pinus halepensis litter & 60 & 89 & $\begin{array}{c}\mathbf{4 . 5 1}(4.27) \\
(1.34-25.48)\end{array}$ & $\begin{array}{c}\mathbf{0 . 2 3}(0.07) \\
(0.11-0.38)\end{array}$ & $\begin{array}{c}1.34(0.34) \\
(0.70-2.08)\end{array}$ & -- & -- & -- \\
\hline Pinus pinaster litter & 56 & 100 & $\begin{array}{c}\mathbf{5 . 7 0}(3.98) \\
(0.47-29.50)\end{array}$ & $\begin{array}{c}\mathbf{0 . 1 9}(0.06) \\
(0.08-0.32)\end{array}$ & -- & $\begin{array}{c}\mathbf{6 4 . 8 3}(23.18) \\
(15.00-100.00)\end{array}$ & $\begin{array}{c}\mathbf{5 8 . 2 3}(22.04) \\
(10.00-95.00)\end{array}$ & $\begin{array}{c}84.61(12.60) \\
(48.61-96.53)\end{array}$ \\
\hline Pinus pinea litter & 35 & 97 & $\begin{array}{c}\mathbf{5 . 5 1}(2.41) \\
(2.00-11.00)\end{array}$ & $\begin{array}{c}\mathbf{0 . 2 6}(0.06) \\
(0.15-0.39)\end{array}$ & $\begin{array}{c}\mathbf{1 . 2 3}(0.27) \\
(0.75-1.72)\end{array}$ & $\begin{array}{c}\mathbf{5 8 . 0 0}(13.68) \\
(25.00-80.00)\end{array}$ & $\begin{array}{c}\mathbf{4 2 . 7 7}(10.84) \\
(18.00-63.00)\end{array}$ & $\begin{array}{c}92.82(1.71) \\
(86.00-95.00)\end{array}$ \\
\hline Quercus faginea litter & 34 & 77 & $\begin{array}{l}12.76(13.06) \\
(4.00-60.00)\end{array}$ & $\begin{array}{c}\mathbf{0 . 1 8}(0.06) \\
(0.10-0.29)\end{array}$ & $\begin{array}{c}\mathbf{0 . 6 8}(0.27) \\
(0.12-1.02)\end{array}$ & $\begin{array}{l}\mathbf{2 0 . 7 2}(12.02) \\
(5.00-50.00)\end{array}$ & $\begin{array}{c}16.72(9.34) \\
(5.00-38.00)\end{array}$ & $\begin{array}{l}\mathbf{5 8 . 6 2}(22.59) \\
(5.00-80.60)\end{array}$ \\
\hline Quercus pubescens litter & 89 & 69 & $\mathbf{8 . 6 0}(15.11)$ & $\mathbf{0 . 2 3}(0.10)$ & $1.16(0.44)$ & -- & -- & -- \\
\hline
\end{tabular}




\begin{tabular}{|c|c|c|c|c|c|c|c|c|}
\hline & & & $(1.37-117.89)$ & $(0.08-0.45)$ & $(0.50-2.65)$ & & & \\
\hline Ulex europaeus litter & 29 & 100 & $\begin{array}{c}\mathbf{5 . 1 9}(8.08) \\
(1.32-44.54)\end{array}$ & $\begin{array}{c}\mathbf{0 . 2 9}(0.12) \\
(0.08-0.51)\end{array}$ & -- & $\begin{array}{c}\mathbf{1 0 0 . 8 5}(36.84) \\
(35.00-160.00)\end{array}$ & $\begin{array}{c}93.22(36.43) \\
(30.00-156.67)\end{array}$ & $\begin{array}{c}\mathbf{9 0 . 8 1}(11.45) \\
(41.41-100.80)\end{array}$ \\
\hline Grasses type 1 & 10 & 100 & $\begin{array}{c}\mathbf{1 . 9 0}(0.99) \\
(1.00-4.00)\end{array}$ & $\begin{array}{c}\mathbf{0 . 9 3}(0.31) \\
(0.40-1.30)\end{array}$ & $\begin{array}{c}\mathbf{2 . 8 4}(0.62) \\
(1.45-3.45)\end{array}$ & $\begin{array}{c}100.00(17.00) \\
(60.00-110.00)\end{array}$ & $\begin{array}{c}\mathbf{7 9 . 0 0}(22.92) \\
(43.00-100.00)\end{array}$ & $\begin{array}{c}96.61(7.18) \\
(77.00-100.00)\end{array}$ \\
\hline Grasses type 2 & 15 & 94 & $\begin{array}{c}\mathbf{3 . 5 3}(5.50) \\
(1.00-22.00)\end{array}$ & $\begin{array}{c}\mathbf{0 . 6 5}(0.07) \\
(0.55-0.72)\end{array}$ & $\begin{array}{c}1.52(0.60) \\
(0.51-1.97)\end{array}$ & $\begin{array}{c}\mathbf{5 8 . 2 1}(32.02) \\
(15.00-100.00)\end{array}$ & $\begin{array}{c}39.86(21.03) \\
(15.00-80.00)\end{array}$ & $\begin{array}{c}\mathbf{8 5 . 1 6}(12.06) \\
(60.00-97.00)\end{array}$ \\
\hline
\end{tabular}


Effect of fuel moisture content and bulk density on the flammability parameters

The multiple linear regression equations derived from the data set for each flammability parameter, with fuel moisture content and bulk density as independent variables, are given in Tables 5.a to 5.f.

Table 5.a. Multiple regression for the time to ignition of the fuel bed

Signification level for the coefficients: ${ }^{(*)}=\mathrm{p}<0.05 ;^{(* *)}=\mathrm{p}<0.001$

TIB: Time to ignition (s), FMC: Fuel moisture content (\%), BD: Bulk density $\left(\mathrm{kg} \mathrm{m}^{-3}\right)$

\begin{tabular}{llcc}
\hline Fuel bed & Multiple regression for TIB & adjusted $\mathbf{R}^{2}$ & p \\
\hline Arbutus unedo & $\mathrm{TIB}=4.619+2.345 \mathrm{FMC}^{(*)}$ & 0.239 & 0.003 \\
Eucalyptus globulus & $\mathrm{TIB}=5.614+0.608 \mathrm{FMC}^{(*)}-0.037 \mathrm{BD}$ & 0.079 & 0.036 \\
Pinus halepensis & $\mathrm{TIB}=-0.578+0.294 \mathrm{FMC}-0.084 \mathrm{BD}$ & 0.180 & 0.001 \\
Pinus pinaster & $\mathrm{TIB}=2.742+0.123 \mathrm{FMC}+0.060 \mathrm{BD}$ & 0.013 & 0.270 \\
Pinus pinea & $\mathrm{TIB}=1.215+0.194 \mathrm{FMC}^{2}+0.170 \mathrm{BD}\left(^{(*)}\right.$ & 0.176 & 0.017 \\
Quercus faginea & $\mathrm{TIB}=13.668+0.901 \mathrm{FMC}^{-0.534 \mathrm{BD}}$ & 0.047 & 0.209 \\
Quercus pubescens & $\mathrm{TIB}=7.466+0.881 \mathrm{FMC}^{(*)}-0.204 \mathrm{BD}$ & 0.036 & 0.087 \\
Ulex europaeus & $\mathrm{TIB}=-5.760+0.542 \mathrm{FMC}^{(*)}+0.290 \mathrm{BD}$ & 0.229 & 0.013 \\
Grasses type 1 & $\mathrm{TIB}=-0.553+0.030 \mathrm{FMC}+1.031 \mathrm{BD}^{(*)}$ & 0.535 & 0.028 \\
Grasses type 2 & $\mathrm{TIB}=-7.833+0.857 \mathrm{FMC}^{(*)}-0.172 \mathrm{BD}$ & 0.267 & 0.061 \\
All fuel beds & $\mathrm{TIB}=3.560+0.292 \mathrm{FMC}^{(*)}-0.059 \mathrm{BD}$ & 0.021 & 0.004 \\
Pinus fuel beds & $\mathrm{TIB}=-129.17-6.399 \mathrm{FMC}+9.843 \mathrm{BD}^{(* *)}$ & 0.239 & 0.000 \\
\hline
\end{tabular}


Table 5.b. Multiple regression for rate of fire spread

Signification level for the coefficients: ${ }^{(*)}=\mathrm{p}<0.05 ;{ }^{(* *)}=\mathrm{p}<0.001$

RoS: Rate of spread $\left(\mathrm{cm} \mathrm{s}^{-1}\right)$, FMC: Fuel moisture content (\%), BD: Bulk density $\left(\mathrm{kg} \mathrm{m}^{-3}\right)$

\begin{tabular}{|c|c|c|c|}
\hline Fuel bed & Multiple regression for $\mathrm{RoS}$ & ted $\mathbf{R}^{2}$ & $\mathbf{p}$ \\
\hline Arbutus unedo & $\mathrm{RoS}=0.113^{(* *)}-0.008 \mathrm{FMC}^{(* *)}$ & 0.570 & 0.000 \\
\hline Eucalyptus globulus & $\mathrm{RoS}=0.284^{(* *)}-0.009 \mathrm{FMC}^{(* *)}-0.001 \mathrm{BD}^{(*)}$ & 0.525 & 0.000 \\
\hline Pinus halepensis & $\mathrm{RoS}=0.391^{(* *)}-0.010 \mathrm{FMC}^{(*)}-0.002 \mathrm{BD}^{(*)}$ & 0.800 & 0.000 \\
\hline Pinus pinaster & $\mathrm{RoS}=0.368^{(* *)}-0.009 \mathrm{FMC}^{(* *)}-0.003 \mathrm{BD}^{(* *)}$ & 0.809 & 0.000 \\
\hline Pinus pinea & $\mathrm{RoS}=0.455^{(* *)}-0.013 \mathrm{FMC}^{(* *)}-0.005 \mathrm{BD}^{(* *)}$ & 0.870 & 0.000 \\
\hline Quercus faginea & $\mathrm{RoS}=0.352^{(* *)}-0.013 \mathrm{FMC}^{(* *)}-0.003 \mathrm{BD}$ & 0.468 & 0.000 \\
\hline Quercus pubescens & $\mathrm{RoS}=0.416^{(* *)}-0.017 \mathrm{FMC}^{(* *)}-0.004 \mathrm{BD}^{(* *)}$ & 0.708 & 0.000 \\
\hline Ulex europaeus & $\mathrm{RoS}=0.520^{(* *)}-0.014 \mathrm{FMC}^{(* *)}-0.005 \mathrm{BD}^{(*)}$ & 0.723 & 0.000 \\
\hline Grasses type 1 & $\mathrm{RoS}=1.470^{(* *)}-0.024 \mathrm{FMC}^{(* *)}-0.017 \mathrm{BD}$ & 0.858 & 0.000 \\
\hline Grasses type 2 & $\mathrm{RoS}=0.623-0.005 \mathrm{FMC}+0.054 \mathrm{BD}$ & 0.030 & 0.418 \\
\hline All fuel beds & $\mathrm{RoS}=0.434-0.004 \mathrm{FMC}^{(* *)}-0.006 \mathrm{BD}^{(* *)}$ & 0.284 & 0.000 \\
\hline Pinus fuel beds & $\mathrm{RoS}=0.392-0.011 \mathrm{FMC}^{(* *)}-0.003 \mathrm{BD}^{(* *)}$ & 0.789 & 0.000 \\
\hline
\end{tabular}

Table 5.c. Multiple regression for rate of fuel bed combustion

Signification level for the coefficients: ${ }^{(*)}=\mathrm{p}<0.05 ;{ }^{(* *)}=\mathrm{p}<0.001$

RoC: Rate of combustion $\left(\mathrm{g} \mathrm{s}^{-1}\right)$, FMC: Fuel moisture content (\%), BD: Bulk density ( $\left.\mathrm{kg} \mathrm{m}^{-3}\right)$

\begin{tabular}{llcc}
\hline Fuel bed & \multicolumn{1}{c}{ Multiple regression for RoC } & adjusted $\mathbf{R}^{2}$ & p \\
\hline Arbutus unedo & $\mathrm{RoC}=0.825^{(* *)}-0.043 \mathrm{FMC}^{(*)}$ & 0.283 & 0,001 \\
Pinus halepensis & $\mathrm{RoC}=2.009^{(* *)}-0.019 \mathrm{FMC}-0.013 \mathrm{BD}$ & 0.408 & 0.000 \\
Pinus pinea & $\mathrm{RoC}=2.028^{(* *)}-0.038 \mathrm{FMC}^{(* *)}-0.029 \mathrm{BD}^{(* *)}$ & 0.611 & 0.000 \\
Quercus faginea & $\mathrm{RoC}=1.421^{(* *)}-0.046 \mathrm{FMC}^{(*)}-0.016 \mathrm{BD}$ & 0.288 & 0.005 \\
Quercus pubescens & $\mathrm{RoC}=1.701^{(* *)}-0.039 \mathrm{FMC}^{(* *)}-0.015 \mathrm{BD}^{(*)}$ & 0.218 & 0.000 \\
Grasses type 1 & $\mathrm{RoC}=3.702^{(*)}-0.045 \mathrm{FMC}^{(* *)}+0.047 \mathrm{BD}$ & 0.753 & 0.003
\end{tabular}




\begin{tabular}{llll} 
Grasses type 2 & $\mathrm{RoC}=3.430-0.190 \mathrm{FMC}+0.108 \mathrm{BD}$ & 0.000 & 0.683 \\
All fuel beds & $\mathrm{RoC}=1.542-0.006 \mathrm{FMC}-0.012 \mathrm{BD}^{(* *)}$ & 0.109 & 0.000 \\
Pinus fuel beds & $\mathrm{RoC}=1.786-0.049 \mathrm{FMC}^{(* *)}-0.006 \mathrm{BD}^{(* *)}$ & 0.426 & 0.000 \\
\hline
\end{tabular}

Table 5.d. Multiple regression for maximum flame height

Signification level for the coefficients: ${ }^{(*)}=\mathrm{p}<0.05 ;{ }^{(* *)}=\mathrm{p}<0.001$

FH (cm): Maximum flame height, FMC: Fuel moisture content (\%), BD: Bulk density $\left(\mathrm{kg} \mathrm{m}^{-3}\right)$

\begin{tabular}{llcl}
\hline Fuel bed & \multicolumn{1}{c}{ Multiple regression for FH } & adjusted $\mathbf{R}^{2}$ & p \\
\hline Eucalyptus globulus & $\mathrm{FH}=120.92^{(* *)}-3.465 \mathrm{FMC}^{(* *)}-0.576 \mathrm{BD}^{(*)}$ & 0.469 & 0.000 \\
Pinus pinaster & $\mathrm{FH}=132.12^{(* *)}-3.157 \mathrm{FMC}^{(* *)}-1.209 \mathrm{BD}^{(* *)}$ & 0.755 & 0.000 \\
Pinus pinea & $\mathrm{FH}=100.28^{(* *)}-2.499 \mathrm{FMC}^{(* *)}-1.303 \mathrm{BD}^{(* *)}$ & 0.668 & 0.000 \\
Quercus faginea & $\mathrm{FH}=50.30^{(* *)}-2.106 \mathrm{FMC}^{(* *)}-0.469 \mathrm{BD}$ & 0.299 & 0.000 \\
Ulex europaeus & $\mathrm{FH}=170.21^{(* *)}-3.821 \mathrm{FMC}^{(* *)}-1.748 \mathrm{BD}^{(*)}$ & 0.648 & 0.000 \\
Grasses type 1 & $\mathrm{FH}=124.29-1.025 \mathrm{FMC}^{(*)}-1.434 \mathrm{BD}^{(*)}$ & 0.408 & 0.000 \\
Grasses type 2 & $\mathrm{FH}=126.68^{(*)}-5.669 \mathrm{FMC}^{(*)}+5.921 \mathrm{BD}^{(* *)}$ & 0.483 & 0.418 \\
All fuel beds & $\mathrm{FH}=99.77-2.273 \mathrm{FMC}^{(* *)}-0.535 \mathrm{BD}^{(*)}$ & 0.159 & 0.000 \\
Pinus fuel beds & $\mathrm{FH}=102.68-3.149 \mathrm{FM}^{(* *)}-0.523 \mathrm{BD}^{(* *)}$ & 0.535 & 0.000 \\
\hline
\end{tabular}

Table 5.e. Multiple regression for mean flame height

Signification level for the coefficients: ${ }^{(*)}=\mathrm{p}<0.05 ;{ }^{(* *)}=\mathrm{p}<0.001$

MFH (cm): Mean flame height, FMC: Fuel moisture content (\%), BD: Bulk density $\left(\mathrm{kg} \mathrm{m}^{-3}\right)$

\begin{tabular}{llll}
\hline Fuel bed & \multicolumn{1}{c}{ Multiple regression for MFH } & $\mathbf{R}^{2}$ adjusted & p \\
\hline Eucalyptus globulus & $\mathrm{MFH}=112.17^{(* *)}-3.374 \mathrm{FMC}^{(* *)}-0.604 \mathrm{BD}^{(*)}$ & 0.415 & 0.000 \\
Pinus pinaster & $\mathrm{MFH}=119.98^{(* *)}-2.891 \mathrm{FMC}^{(* *)}-1.110 \mathrm{BD}^{(* *)}$ & 0.700 & 0.000 \\
Pinus pinea & $\mathrm{MFH}=78.16^{(* *)}-2.142 \mathrm{FMC}^{(* *)}-1.059 \mathrm{BD}^{(* *)}$ & 0.758 & 0.000 \\
Quercus faginea & $\mathrm{MFH}=41.31^{(* *)}-1.632 \mathrm{FMC}^{(* *)}-0.448 \mathrm{BD}$ & 0.312 & 0.002 \\
Ulex europaeus & $\mathrm{MFH}=159.86^{(* *)}-3.835 \mathrm{FMC}^{(* *)}-1.570 \mathrm{BD}^{(*)}$ & 0.610 & 0.000 \\
Grasses type 1 & $\mathrm{MFH}=111.97^{(* *)}-1.690 \mathrm{FMC}^{(* *)}+1.614 \mathrm{BD}^{(* 10}$ & 0.812 & 0.001
\end{tabular}




\begin{tabular}{llll} 
Grasses type 2 & $\mathrm{MFH}=82.51^{(*)}-3.484 \mathrm{FMC}^{(*)}+3.217 \mathrm{BD}$ & 0.393 & 0.025 \\
All fuel beds & $\mathrm{MFH}=86.73-2.348 \mathrm{FMC}^{(* *)}-0.353 \mathrm{BD}^{(*)}$ & 0.173 & 0.000 \\
Pinus fuel beds & $\mathrm{MFH}=82.78-2.887 \mathrm{FM}^{(* *)}-0.241 \mathrm{BD}^{(*)}$ & 0.411 & 0.000 \\
\hline
\end{tabular}

Table 5.f. Multiple regression for fuel comsumption ratio

Signification level for the coefficients: ${ }^{(*)}=\mathrm{p}<0.05 ;^{(* *)}=\mathrm{p}<0.001$

FCR (\%): Fuel consumption ratio, FMC: Fuel moisture content (\%), BD: Bulk density $\left(\mathrm{kg} \mathrm{m}^{-3}\right)$

\begin{tabular}{|c|c|c|c|}
\hline Fuel bed & Multiple regression for FCR & adjusted $R^{2}$ & $\mathbf{p}$ \\
\hline$\overline{\text { Eucalyptus globulus }}$ & $\mathrm{FCR}=126.83^{(* *)}-0.877 \mathrm{FMC}-1.107 \mathrm{BD}^{(*)}$ & 0.187 & 0.000 \\
\hline Pinus pinaster & $\mathrm{FCR}=131.94^{(* *)}-0.418 \mathrm{FMC}-1.286 \mathrm{BD}^{(* *)}$ & 0.682 & 0.000 \\
\hline Pinus pinea & $\mathrm{FCR}=95.39^{(* *)}-0.114 \mathrm{FMC}-0.103 \mathrm{BD}^{(*)}$ & 0.108 & 0.061 \\
\hline Quercus faginea & $\mathrm{FCR}=131.59^{(* *)}-3.344 \mathrm{FMC}^{(*)}-2.275 \mathrm{BD}^{(*)}$ & 0.320 & 0.001 \\
\hline Ulex europaeus & $\mathrm{FCR}=106.58^{(* *)}-0.600 \mathrm{FMC}^{(*)}-0.513 \mathrm{BD}$ & 0.167 & 0.035 \\
\hline Grasses type 1 & $\mathrm{FCR}=108.23^{(* *)}-0.468 \mathrm{FMC}^{(*)}-0.939 \mathrm{BD}$ & 0.523 & 0.031 \\
\hline Grasses type 2 & $\mathrm{FCR}=85.94-1.019 \mathrm{FMC}+6.923 \mathrm{BD}$ & 0.000 & 0.642 \\
\hline All fuel beds & $\mathrm{FCR}=105.21-0.656 \mathrm{FMC}^{(*)}-0.659 \mathrm{BD}^{(* *)}$ & 0.165 & 0.000 \\
\hline Pinus fuel beds & $\mathrm{FCR}=113.23-0.372 \mathrm{FM}-0.859 \mathrm{BD}^{(* *)}$ & 0.584 & 0.000 \\
\hline
\end{tabular}

In the case of woody species litter, both moisture content and bulk density, for the considered ranges, generally produce a significant effect on the rate of spread of the fire (Table 5.b) and on the maximum and mean flame height (Tables 5.d and 5.e). The coefficients are negative, so these parameters increase when either fuel moisture content and bulk density decrease. Nevertheless, the effect of bulk density is not significant in the tests for the rate of spread with Quercus faginea litter. The adjusted $\mathrm{R}^{2}$ values for coniferous species are higher than the values for hardwood species. This is probably due to the fact that needles constitute more homogeneous fuel beds than leaves. On the contrary, for the litter of Pinus pinaster, Quercus faginea and Q. pubescens, neither the fuel moisture content nor the bulk density have a significant effect on the time to ignition of fuel beds (Table 5.a). However, this result is not in contradiction with classical bibliography (e.g. Trabaud 1976; Valette 1988; Hernando 1989) which highlights an increase of the time to ignition of forest fuel with increasing fuel moisture content. The difference is due to the method used in this work. In previously mentioned studies, flammability is 
induced using a calorific focus on which the samples of vegetation are laid, and a pilot flame that contribute to the ignition of the gases, whereas, in the present study, the heat source is an ignited piece of wood and the fuel is composed of a continuous stratum. Nonetheless, when the effect of independent variables is significant, their influence is positive, so the time to ignition increases with the increasing moisture content or bulk density. Exceptions apart, a significant effect of independent variables has not been established on the rate of combustion (Table 5.c) or on the fuel consumption ratio (Table 5.f). However, when these variables have a significant effect, it is negative. Therefore, both rates (of combustion and of spread) are positively correlated, with coefficients varying between 0.550 and 0.902 . In the case of grasses, fuel moisture content generally produces a significant effect on the parameters of flammability; this effect is negative, except for time to ignition. Bulk density does not have a significant effect on these parameters.

On the whole, an increase of the moisture content and bulk density of litters implies an increase of the values of time to ignition and a reduction of the other parameters. Focusing on the effect of fuel moisture content, grasses are more sensitive to the effect of this factor than other litter, the Arbutus unedo litter being the least sensitive fuel bed to FMC changes.

If data set of all the fuel beds or all the Pinus litters are merged to calculate the flammability parameters (Table 5.a to 5.e), equations obtained in this case are significant for all these parameters. Therefore, for the considered ranges and selected methodology, fuel type is not significant in the variation of the flammability parameters.

Table 6 shows the logistic model of prediction of the ignition probability for the merged fuel beds $(P$. halepensis, $Q$. pubescens, A. unedo litter beds) as a function bulk density (BD) and fuel moisture content (FMC).

Table 6. Model of prediction for ignition probability

$\begin{array}{r}\hline \text { Merged fuel beds }(\mathbf{N}=\mathbf{2 8 2}) \\ \qquad \begin{array}{c}\mathrm{p}(\mathrm{i})=\mathrm{e}^{\mathrm{z}} / 1+\mathrm{e}^{\mathrm{z}} \\ \text { with } \mathrm{z}=1.155+0.032 * \mathrm{BD}-13.925 * \mathrm{FMC}\end{array} \\ \hline\end{array}$

p(i) : probability of ignition ; BD : bulk density ; FMC : fuel moisture content 
The both variables of the model are statistically significant (BD: Chi-square=7.13, p=0.0076 ; FMC: Chisquare $=9.74, \mathrm{p}=0.0018$ ). The results of the logistic regression show that there is a significant relationship between these variables $(\mathrm{p}<0.05)$. BD contributes positively and moderately to the ignition probability (for each $\mathrm{kg} / \mathrm{m}^{3}$ of $\mathrm{BD}$, the ignition probability increases 1.032 times). This could be due to the fact that there are only 4 different values of BD in the dataset. FMC is negatively related to the ignition probability but its contribution is very low (for each \% of FMC, the ignition probability decreases $910^{-7}$ time). This is due to the low range of FMC values (1\% to $11 \%$ ) because the litter beds had been previously dried (air-dried or oven-dried). The goodness of fit Chi-square, used to test if the model fits the data, shows that the logistic regression does not adequately fit the observed data (Chi-square $=13.77, \mathrm{p}=0.003)$.

Comparison of regression lines for the prediction of the Rate of Spread

The linear regression models for the prediction of Rate of Spread $\left(\operatorname{RoS}^{4}\right)$ with fuel moisture content (FMC) as independent variable were compared, grouping fuel beds in four types (Figure 3): (1) Pinus litters (Pinus halepensis, P. pinaster and P. pinea), (2) hardwood litters (Eucalyptus globulus, Quercus faginea and Q. pubescens), (3) bush litters (Arbutus unedo and Ulex europaeus), and (4) grasses (type 1 and type 2). In this comparison, bulk density is not considered. Therefore, each RoS vs FMC relationship is established for a fuel bed type presenting a range of bulk densities.

For the Pinus litters, the conditional sum of squares shows that there are statistically significant differences among the slopes and among the intercepts for the various values of Pinus litters, so the regression coefficients of the RoS relationships for the three Pinus litters are different. Pinus halepensis litter is more sensitive to fuel moisture content variations $\left(\mathrm{R}^{2}=0.79\right)$, and $P$. pinaster litter the least sensitive $\left(\mathrm{R}^{2}=0.52\right)$. When the FMC is low $(<5 \%)$, the highest RoS value is obtained with P. pinea litter, and the lowest with P. pinaster litter.

For the hardwood litters, the conditional sum of squares indicates that there are statistically significant differences among the slopes and among the intercepts for the various values of hardwood litters. As shown in Figure 3, Eucalyptus globulus litter is the least sensitive to FMC variations $\left(\mathrm{R}^{2}=0.48\right)$ and Quercus pubescens

\footnotetext{
${ }^{4}$ It is important to stress that, in this work, RoS is the time required by the fire to reach one side of the sample, corresponding to a distance of $0.35 \mathrm{~m}$ and no wind.
} 

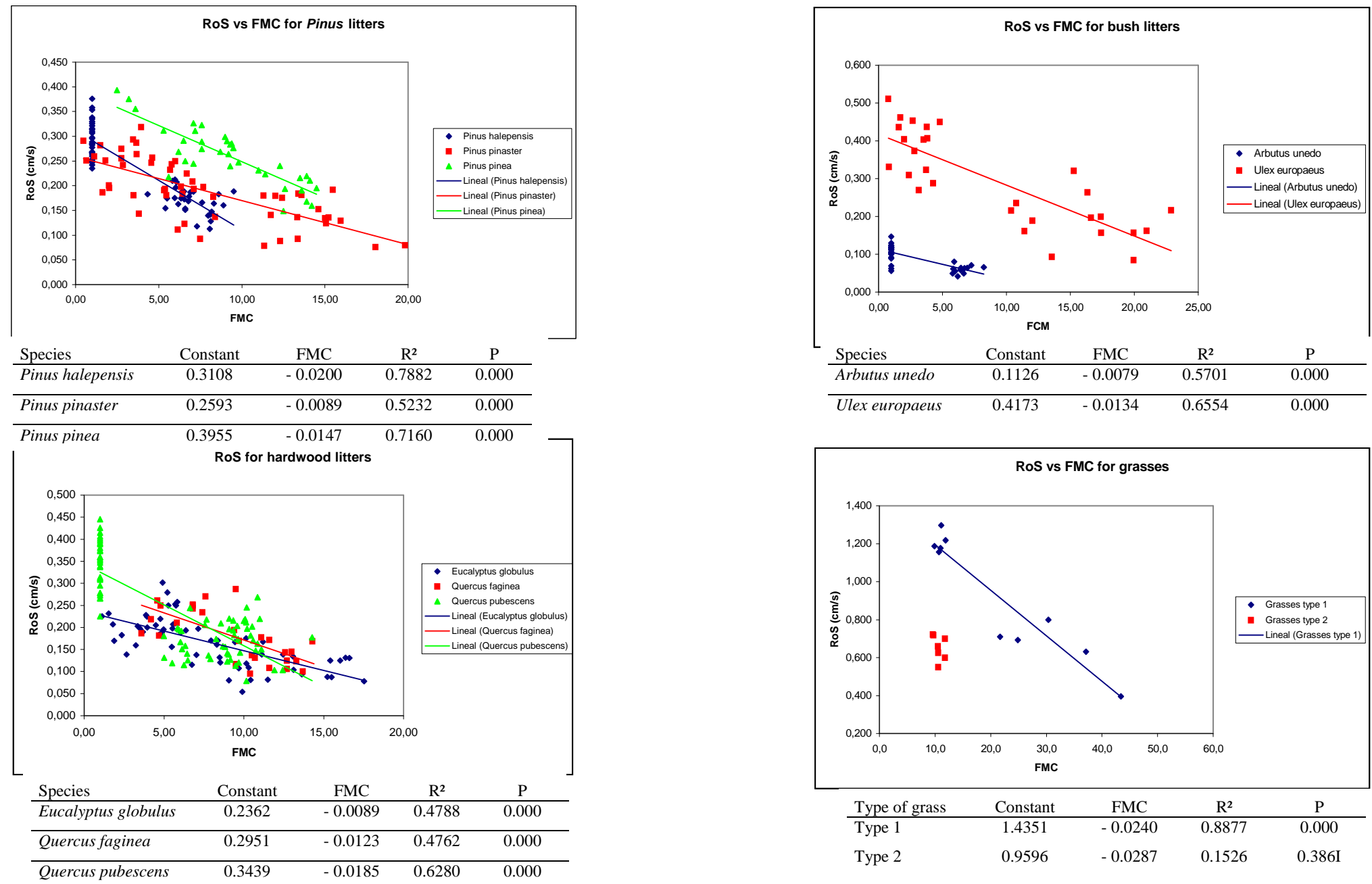

Fig. 3. Prediction of different fuel bed rates of spreąd (RoS) according to the fuel moisture content (FMC) using linear regression models.

Mis en forme : Police :10 pt,

RoS has been calculated for a distance of $0.35 \mathrm{~cm}$, and no wind. 
the most sensitive $\left(\mathrm{R}^{2}=0.63\right)$. When the FMC is low, the lowest RoS value is obtained with the Eucalyptus litter and the highest with Quercus pubescens litter.

For the bush litters, the conditional sum of squares indicates that there are statistically significant differences between the intercepts of both bush litters, but not between the slopes, so both litters have a similar sensitivity to FMC variations. When it is low, the RoS of the Ulex litter is higher than the RoS of the Arbutus one.

For the grasses, the conditional sum of squares indicates that there are statistically significant differences between the intercepts of both grasses. When FMC is low, the RoS of type 1 is higher than the RoS of type 2, but for this last type, no high values of FMC were recorded.

\section{Firebrands tests}

In this experiment, 3669 samples were tested to assess the capability of several types of firebrands to ignite fuel beds, under different conditions. Table 7 presents the results concerning the ignition frequency of the selected fuel beds according to different states of firebrand (flaming or glowing), with or without air flow.

Effect of air flow, firebrand and fuel bed on the fuel bed ignition frequency

The highest ignition frequencies are obtained with flaming firebrands (and no air flow), for all fuel beds (Table 7). With Pinus halepensis, the ignition frequencies are always higher than 50\% (Table 7.a). With the glowing firebrands and an air flow of $0.8 \mathrm{~m} \mathrm{~s}^{-1}$, whatever the direction, the results are lower than $50 \%$, with the exception of a) P. halepensis cone on Pinus pinea needle bed $(92.5 \%, 67.5 \%)$, b) P. halepensis cone on grass bed with oblique air flow direction $(67.5 \%)$, c) $P$. pinea cone scales on $P$. pinea needle bed with oblique air flow direction (57\%) and d) Eucalyptus globulus bark on Pinus pinaster needle bed whatever the air flow direction $(82.5 \%, 55 \%)$. Generally, when the air flow direction is oblique, the results are higher than when the air flow direction is horizontal (Table 7.b). Indeed, the statistical tests (Kruskal-Wallis) show that the effect of air flow is significant for the tested firebrands and fuel beds $(\mathrm{KW}=1040.73 ; \mathrm{p}=0.000)$, the lowest frequencies $(12.55 \%)$ occurring with horizontal air flow (at $0.8 \mathrm{~m} \mathrm{~s}^{-1}$ and with glowing firebrands) and the highest ones with no air flow but with flaming firebrands (72.57\%). In order to remove the effect of the firebrand state (flaming or glowing), the test was performed without the data obtained with no air flow. The result remains the same $(\mathrm{KW}=$ $76.49 ; \mathrm{p}=0.000)$ and the highest frequencies $\left(31.75 \%\right.$ ) occur here with the air flow of $4.5 \mathrm{~m} \mathrm{~s}^{-1}$ (oblique 
Table 7. Ignition frequency $(\%)$ of the fuel beds according to the type of firebrands, their state and test conditions

a. Flaming firebrands, Air flow $=0 \mathrm{~m} \mathrm{~s}^{-1}, \mathrm{~N}=40, \mathrm{FMC}$ : Fuel moisture content (average data)

\begin{tabular}{|c|c|c|c|c|c|}
\hline Firebrand & $\begin{array}{l}\text { Pinus halepensis needle bed } \\
\qquad \text { (Air-dried FMC }=3.9 \% \text { ) }\end{array}$ & $\begin{array}{l}\text { Pinus pinea needle bed } \\
\qquad(\mathrm{FMC}=11.3 \%)\end{array}$ & $\begin{array}{l}\text { Pinus pinaster needle bed } \\
\qquad(\mathrm{FMC}=3.98 \%)\end{array}$ & $\begin{array}{l}\text { Eucalyptus globulus leaf bed } \\
\qquad(\mathrm{FMC}=3.3 \%)\end{array}$ & $\begin{array}{l}\text { Cured grass bed } \\
(\mathrm{FMC}=9.2 \%)\end{array}$ \\
\hline P. halepensis twig & 97.5 & & & & \\
\hline P. halepensis bark & 55 & & & & \\
\hline P. halepensis cone scale & 100 & & & & \\
\hline P. halepensis cone & & 100 & & & 95 \\
\hline Quercus ilex leaf & 92.5 & 80 & & & 82.5 \\
\hline Quercus ilex acorn & & 40 & & & 47.5 \\
\hline Quercus suber bark & 65 & & & & \\
\hline P. pinea twig & & 77.5 & & & 75 \\
\hline P. pinea bark & & 35 & & & 80 \\
\hline$P$. pinea cone scale & & 37.5 & & & 72.5 \\
\hline$P$. pinaster bark & & & 42.5 & 32.5 & \\
\hline P. pinaster cone scale & & & 100 & 100 & \\
\hline Pinus radiata bark & & & 45 & 20 & \\
\hline E. globulus bark & & & 97.5 & 100 & \\
\hline E. globulus leaf & & & $97.5(\mathrm{~N}=39)$ & 90 & \\
\hline
\end{tabular}


b. Glowing firebrands, Air flow $=0.8 \mathrm{~m} \mathrm{~s}^{-1}$, oblique or horizontal direction, N = 40, FMC: Fuel moisture content (average data)

\begin{tabular}{|c|c|c|c|c|c|c|c|c|}
\hline \multirow[b]{2}{*}{ Firebrand } & \multicolumn{2}{|c|}{$\begin{array}{l}\text { Pinus pinea needle bed } \\
\qquad(\mathrm{FMC}=11.3 \%)\end{array}$} & \multicolumn{2}{|c|}{$\begin{array}{l}\text { Pinus pinaster needle bed } \\
\qquad(\mathrm{FMC}=3.98 \%)\end{array}$} & \multicolumn{2}{|c|}{$\begin{array}{l}\text { Eucalyptus globulus leaf bed } \\
(\mathrm{FMC}=3.3 \%)\end{array}$} & \multicolumn{2}{|c|}{$\begin{array}{l}\text { Cured grass bed } \\
(\mathrm{FMC}=9.2 \%)\end{array}$} \\
\hline & \multirow[b]{2}{*}{ oblique } & \multirow[b]{2}{*}{ Horizontal } & \multirow[b]{2}{*}{ oblique } & \multirow[b]{2}{*}{ horizontal } & \multirow[b]{2}{*}{ oblique } & \multirow[b]{2}{*}{ horizontal } & \multirow[b]{2}{*}{ oblique } & \multirow[b]{2}{*}{ horizontal } \\
\hline Air flow & & & & & & & & \\
\hline P. halepensis cone & 92.5 & 67.5 & & & & & 67.5 & 17.5 \\
\hline Quercus ilex leaf & 2.5 & 0 & & & & & 0 & 0 \\
\hline Quercus ilex acorn & 37.5 & 12.5 & & & & & 0 & 0 \\
\hline$P$. pinea twig & 2.5 & 0 & & & & & 12.5 & 15 \\
\hline$P$. pinea bark & 22.5 & 5 & & & & & 17.5 & 2.5 \\
\hline$P$. pinea cone scale & 57.5 & 10 & & & & & 7.5 & 5 \\
\hline$P$. pinaster bark & & & 20 & $15.4(\mathrm{~N}=64)$ & 2.5 & 12.5 & & \\
\hline$P$. pinaster cone scale & & & 0 & 5 & 0 & $2.4(\mathrm{~N}=41)$ & & \\
\hline Pinus radiata bark & & & 2.5 & 17.5 & $0(\mathrm{~N}=41)$ & 7.5 & & \\
\hline E. globulus bark & & & 82.5 & 55 & 20 & $22.5(\mathrm{~N}=45)$ & & \\
\hline E. globulus leaf & & & 2.5 & $0(\mathrm{~N}=39)$ & 0 & 0 & & \\
\hline
\end{tabular}


c. Glowing firebrands, Air flow $=2.5$ or $4.5 \mathrm{~m} \mathrm{~s}^{-1}$, oblique direction, $\mathrm{N}=40$

\begin{tabular}{|c|c|c|c|c|}
\hline \multirow{2}{*}{$\begin{array}{l}\text { Pinus halepensis needle bed } \\
\text { Firebrands } \\
\\
\text { Airflow }\end{array}$} & \multicolumn{2}{|c|}{ (Air-dried FMC=3.9\%) } & \multicolumn{2}{|c|}{ (Oven-dried $\mathrm{FMC}=0 \%$ ) } \\
\hline & $2.5 \mathrm{~ms}^{-1}$ & $4.5 \mathrm{~m} \mathrm{~s}^{-1}$ & $2.5 \mathrm{~ms}^{-1}$ & $4.5 \mathrm{~ms} \mathrm{~s}^{-1}$ \\
\hline P. halepensis twig & 7.5 & 47.5 & 32.5 & 65 \\
\hline P. halepensis bark & 35 & 60 & 30 & 62.5 \\
\hline P. halepensis cone scale & 0 & 7.5 & 0 & 10 \\
\hline Quercus ilex leaf & 5 & 0 & 0 & 0 \\
\hline Quercus suber bark & 17.5 & 12.5 & 10 & 52.5 \\
\hline
\end{tabular}


direction). The ignition frequency increases with the air flow value. When the air flow directions (oblique and horizontal at $0.8 \mathrm{~m} \mathrm{~s}^{-1}$ ) are compared (Mann-Whitney test performed only on data presenting an ignition frequency $>50 \%$ ), the ignition frequencies are significantly higher with the oblique air flow (than with the horizontal one $(87.5 \%$ vs $61.25 \% ; \mathrm{KW}=840 ; \mathrm{p}=0.0001)$. The effect of the air flow (ignition frequencies at 2.5 $\mathrm{m} \mathrm{s}^{-1} v s$ ignition frequencies at $4.5 \mathrm{~m} \mathrm{~s}^{-1}$ ) was not tested because of the low ignition frequencies obtained in the experiment (Table 7c).

The effect of firebrand type is also significant $(\mathrm{KW}=586.29 ; \mathrm{p}=0.000)$, the lowest frequencies occurring with E. globulus and Q. ilex leaves (0.63\%) and the highest ones with P. halepensis cone (61.25\%) which seems the most efficient firebrand to ignite a fuel bed. If the test is performed only on the data obtained with no air flow and flaming firebrands, the result remains the same $(\mathrm{KW}=319.95 ; \mathrm{p}=0.000)$, the highest rates occurring with P. pinaster and P. halepensis cone scales (100\%) and the lowest ones with Pinus radiata bark (32.50\%).

The effect of fuel bed type is significant on the ignition frequency $(\mathrm{KW}=82.88 ; \mathrm{p}=0.000)$ with the lowest frequencies occurring with the E. globulus leaf bed (6.88\%) and the highest ones with the oven-dried P. halepensis needle bed (26.25\%). If the test is performed only on the data obtained with no air flow and flaming firebrands, the result remains the same $(\mathrm{KW}=29.16 ; \mathrm{p}=0.000)$, the highest frequencies occurring here with air-dried P. halepensis needle bed $(82.00 \%)$ and the lowest ones with $P$. pinea needle bed $(61.25 \%)$. In Table 7.c, the results obtained with oven-dried $P$. halepensis needle bed are generally higher than with an airdried fuel bed, and with an air flow of $4.5 \mathrm{~m} \mathrm{~s}^{-1}$, whatever the type of glowing firebrands. The statistical test performed to test the effect of fuel bed moisture content (Mann-Whitney test performed only on data presenting an ignition frequency $>50 \%$ ) shows that the ignition frequencies obtained with air-dried $P$. halepensis needle bed are not significantly different from those obtained with oven-dried $P$. halepensis needle one $(\mathrm{W}=-40 ; \mathrm{p}=$ $0.87)$.

The important role of the type of fuel bed, of firebrand, of FMC and of air flow has been previously noted by several authors. Baker (2005) and Babrauskas (2002) reported that, for Douglas-fir trees with a moisture content exceeding $70 \%$ it was not possible to sustain burning after ignition, whereas between 30 and $70 \%$ moisture content the burning will be partial, and below $30 \%$ the burning will be total after ignition. Manzello et al. (2006c), using firebrands from Douglas-fir tree, were unable to sustain a flaming ignition when shredded hardwood mulch beds were held at $11 \%$ moisture content but succeeded if the fuel bed was dry. Whatever the moisture content, they obtained ignitions with flaming firebrands for pine straw mulch beds and they showed the 
influence of FMC and air flow on ignition events in grass beds. Ellis (2000) obtained a 100\% ignition frequency with no air flow and flaming eucalyptus firebrand when the fuel bed moisture content was less than $9 \%$ and no ignition when glowing firebrands were used in the same conditions. However, with an air flow of $1 \mathrm{~m} \mathrm{~s}^{-1}$ and a FMC $<3 \%$, they were able to obtain up to $50 \%$ ignition frequency. Manzello et al. (2006a) produced flaming ignition of pine needle bed (FMC from 0 to 11\%) using a flaming firebrand (Pinus ponderosa) with an air flow of $0.5 \mathrm{~m} \mathrm{~s}^{-1}$. No ignitions were observed as a consequence of single glowing firebrand, even with an air flow of $1 \mathrm{~m} \mathrm{~s}^{-1}$ in contrast to Ellis (2000) who used Eucalyptus sp. as a firebrand. In Manzello et al.'s experiments (2006a), the fuel bed ignition was only possible with glowing firebrand if there were more than one firebrand (4 in the study) released on the fuel bed. Moreover, Manzello et al. (2006b) showed that the flux of firebrands, their size and the degree of air flow are important parameters to determine the ignition propensity of a fuel bed.

\section{Effect of air flow, firebrand and fuel bed on the fuel beds time-to-ignition}

Table 8 shows the time-to-ignition of the different fuel beds according to the firebrand type and to the conditions chosen for the experiment. With no air flow and flaming firebrands, the time-to-ignition values vary from $2.5 \mathrm{~s}$ (Pinus pinea bark on grass bed) to $12.56 \mathrm{~s}$ ( $P$. pinea cone scales on $P$. pinea needle bed), depending on the fuel bed and the state of the firebrands used in the experiment (Table 8.a). The Q. ilex leaves always give the shortest time to ignition values $(3.09$ s, 3.66 s) whatever the fuel bed, on the contrary, the results with Pinus pinaster bark are always high (10.53 s, 7.23 s), whatever the fuel bed. With Pinus halepensis needle bed and glowing firebrands (Table 8.c), the time-to-ignition generally decreases when the air flow increases whatever the moisture content of the fuel bed. Here, the air flow seems to be the factor with the strongest effect. Indeed, the non-parametric test (Kruskal-Wallis) performed on the time to ignition data show that the effect of air flow is significant for the tested firebrands (test only performed on samples of fuel beds having burnt; KW = 551.29; $\mathrm{p}=$ 0.000). The highest values occur with an air flow of $2.5 \mathrm{~m} \mathrm{~s}^{-1}$ (oblique direction) and glowing firebrands (43.55 s in average) and the lowest ones with no air flow but with flaming firebrands (5.42 s in average). As before, with the ignition frequency, these low values result more from the flaming firebrands than the absence of air flow. In order to remove this effect, the test was performed without the data obtained with no air flow and flaming firebrands. The air flow effect remains significant $(\mathrm{KW}=12.06 ; \mathrm{p}=0.007)$ and the lowest values occur with an air flow of $4.5 \mathrm{~m} \mathrm{~s}^{-1}$ and an oblique direction (23.51 s in average). This last type of air flow seems to be the most efficient to ignite a fuel bed, and in order to confirm this result, the air flow directions (oblique and horizontal, at 
Table 8. Time-to-ignition (s) of the fuel beds according to the different firebrands and tested conditions (mean and standard deviation). -: no ignition of the fuel bed a. Flaming firebrands, Air flow $=0 \mathrm{~m} \mathrm{~s}^{-1}$, FMC: Fuel moisture content, $\mathrm{N}=40$

\begin{tabular}{|c|c|c|c|c|c|}
\hline Firebrand & $\begin{array}{l}\text { Pinus halepensis needle bed } \\
\text { (Air-dried FMC }=3.9 \% \text { ) }\end{array}$ & $\begin{array}{l}\text { Pinus pinea needle bed } \\
(\mathrm{FMC}=11.3 \%)\end{array}$ & $\begin{array}{l}\text { Pinus pinaster needle bed } \\
\qquad(\mathrm{FMC}=3.98 \%)\end{array}$ & $\begin{array}{l}\text { Eucalyptus globulus leaf bed } \\
\qquad(\mathrm{FMC}=3.3 \%)\end{array}$ & $\begin{array}{l}\text { Cured grass bed } \\
(\mathrm{FMC}=9.2 \%)\end{array}$ \\
\hline P. halepensis twig & $\begin{array}{l}7.99(6.11) \\
1.73-39.2\end{array}$ & & & & \\
\hline P. halepensis bark & $\begin{array}{l}7.63(3.69) \\
2.55-18.83\end{array}$ & & & & \\
\hline P. halepensis cone scale & $\begin{array}{l}\mathbf{5 . 2 8}(2.39) \\
2.32-12.67\end{array}$ & & & & \\
\hline P. halepensis cone & 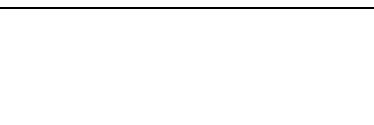 & $\begin{array}{c}\mathbf{4 . 4 0}(3.34) \\
1-18\end{array}$ & & & $\begin{array}{c}8.74(13.31) \\
1-64\end{array}$ \\
\hline Quercus ilex leaf & $\begin{array}{l}3.66(2.56) \\
1.41-13.86\end{array}$ & $\begin{array}{c}3.66(1.29) \\
1-6\end{array}$ & & & $\begin{array}{c}\mathbf{3 . 0 9}(1.31) \\
1-8\end{array}$ \\
\hline Quercus ilex acorn & 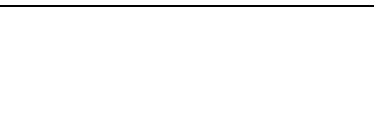 & $\begin{array}{c}\mathbf{5 . 3 8}(3.12) \\
2-15\end{array}$ & & & $\begin{array}{c}\mathbf{3 . 8 9}(1.79) \\
1-8\end{array}$ \\
\hline Quercus suber bark & $\begin{array}{l}\mathbf{8 . 0 1}(3.12) \\
2.67-15.73\end{array}$ & & & & \\
\hline$P$. pinea twig & & $5.39(4.18)$ & & & $3.81(3.24)$ \\
\hline
\end{tabular}




\begin{tabular}{|c|c|c|c|c|}
\hline & $2-17$ & & & $1-19$ \\
\hline \multirow[t]{2}{*}{$P$. pinea bark } & $8.21(4.48)$ & & & $2.50(1.61)$ \\
\hline & $3-19$ & & & $1-7$ \\
\hline \multirow[t]{2}{*}{ P. pinea cone scale } & $\mathbf{1 2 . 5 6}(5.37)$ & & & $4.41(6.79)$ \\
\hline & $5-22$ & & & $1-30$ \\
\hline \multirow[t]{2}{*}{ P. pinaster bark } & & $\mathbf{1 0 . 5 3}(13.96)$ & $\mathbf{7 . 2 3}(3.32)$ & \\
\hline & & $1-62$ & $3-12$ & \\
\hline \multirow[t]{2}{*}{$P$. pinaster cone scale } & & $4.95(1.95)$ & $\mathbf{5 . 4 0}(3.44)$ & \\
\hline & & $1-11$ & $2-18$ & \\
\hline \multirow[t]{2}{*}{ Pinus radiata bark } & & $9.06(9.96)$ & $\mathbf{6 . 0 0}(3.16)$ & \\
\hline & & $4-48$ & $3-13$ & \\
\hline \multirow[t]{2}{*}{ E. globulus bark } & & $3.87(0.86)$ & $\mathbf{4 . 0 5}(1.08)$ & \\
\hline & & $2-5$ & $2-8$ & \\
\hline \multirow[t]{2}{*}{ E. globulus leaf } & & $3.64(1.22)$ & $\mathbf{5 . 3 3}(2.50)$ & \\
\hline & & $2-7$ & $2-12$ & \\
\hline
\end{tabular}


b. Glowing firebrands, Air flow $=0.8 \mathrm{~m} \mathrm{~s}^{-1}$, oblique or horizontal direction, FMC: Fuel moisture content, $\mathrm{N}=40$

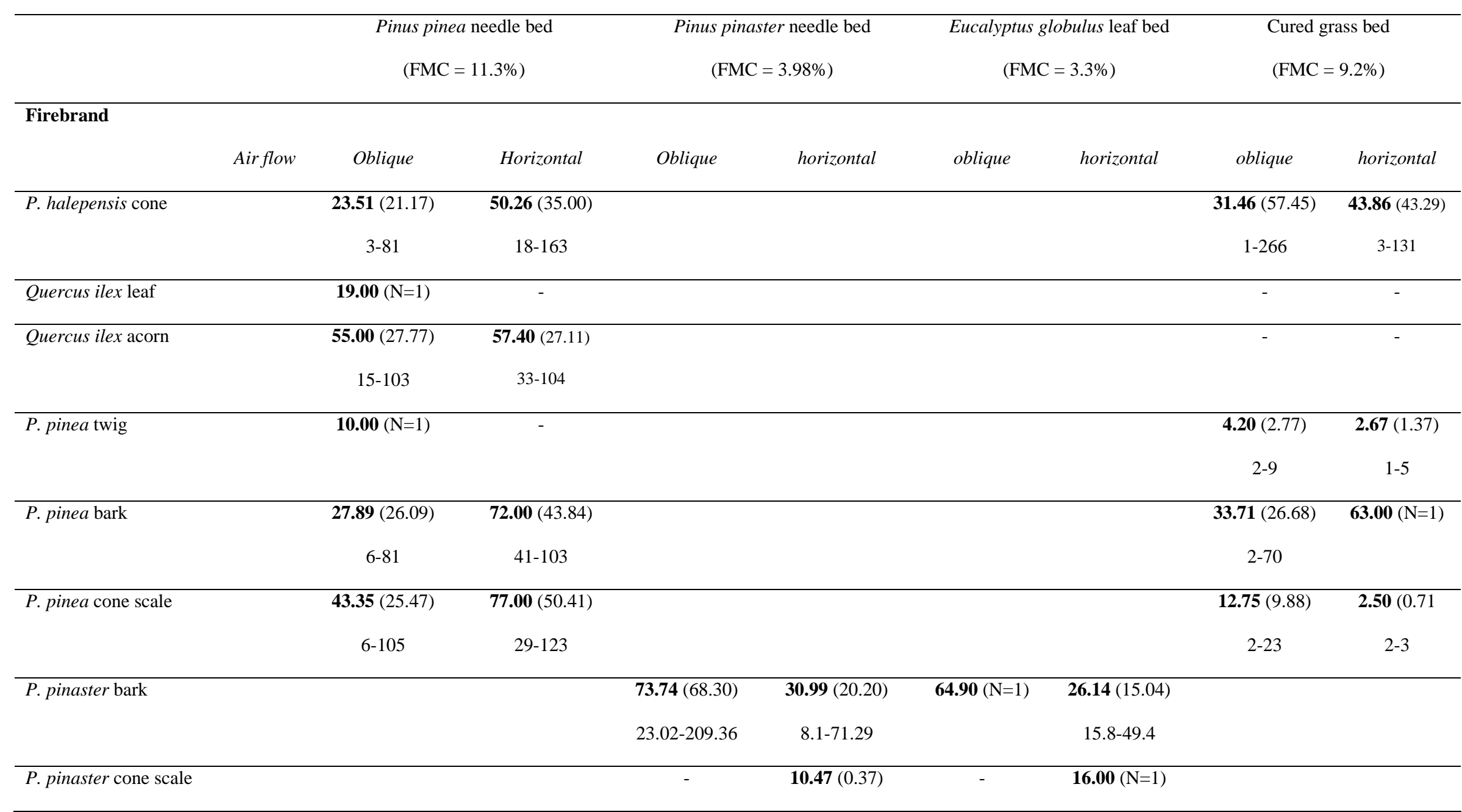




\begin{tabular}{|c|c|c|c|c|}
\hline & & $10.21-10.73$ & & \\
\hline \multirow[t]{2}{*}{ Pinus radiata bark } & $69.90(\mathrm{~N}=1)$ & $\mathbf{5 4 . 6 8}(45.80)$ & - & $\mathbf{6 3 . 3 9}(47.62)$ \\
\hline & & $7.08-119.75$ & & $26.9-117.26$ \\
\hline \multirow[t]{2}{*}{ E. globulus bark } & $14.99(9.87)$ & $\mathbf{1 0 . 2 8}(5.40)$ & $9.10(6.75)$ & $15.09(2.89)$ \\
\hline & $5.38-55.4$ & $3.16-27.11$ & $2.79-24.88$ & $11.8-20.6$ \\
\hline E. globulus leaf & $13.96(\mathrm{~N}=1)$ & - & - & - \\
\hline
\end{tabular}

c. Glowing firebrands, Air flow $=2.5$ or $4.5 \mathrm{~m} \mathrm{~s}^{-1}$, oblique direction, $\mathrm{N}=40$

\begin{tabular}{|c|c|c|c|c|}
\hline Pinus halepensis needle bed & \multicolumn{2}{|c|}{ (Air-dried FMC=3.9\%) } & \multicolumn{2}{|c|}{ (Oven-dried FMC=0\%) } \\
\hline Air flow & $2.5 \mathrm{~m} \mathrm{~s}^{-1}$ & $4.5 \mathrm{~ms}^{-1}$ & $2.5 \mathrm{~ms}^{-1}$ & $4.5 \mathrm{~ms}^{-1}$ \\
\hline \multirow[t]{2}{*}{ P. halepensis twig } & $16.49(12.36)$ & $20.04(16.47)$ & $\mathbf{1 7 . 5 6}(19.31)$ & $14.35(17.51)$ \\
\hline & $7.64-30.61$ & $4.14-54.69$ & $1.58-68.06$ & $3.8-77.99$ \\
\hline \multirow[t]{2}{*}{ P. halepensis bark } & $55.68(52.36)$ & $19.29(12.26)$ & $28.00(26.15)$ & $25.13(19.12)$ \\
\hline & $11.66-187.03$ & $6.35-54.55$ & $7.02-103.71$ & $2.69-87.81$ \\
\hline \multirow[t]{2}{*}{ P. halepensis cone scale } & - & $24.61(26.92)$ & - & $\mathbf{1 0 . 0 1}(2.75)$ \\
\hline & & $7.11-55.6$ & & $6.24-12.39$ \\
\hline
\end{tabular}




\begin{tabular}{ccccc}
\hline Quercus ilex leaf & $\mathbf{1 3 . 1 6}(0.18)$ & - & - & - \\
& $13.03-13.28$ & & & \\
\hline Quercus suber bark & $\mathbf{9 4 . 6 8}(39.55)$ & $\mathbf{4 6 . 5 9}(32.74)$ & $\mathbf{7 8 . 2 4}(43.11)$ & $\mathbf{3 7 . 8 3}(33.48)$ \\
& $25.33-153.38$ & $6.3-87.54$ & $28.5-130.57$ & $1.25-127.88$ \\
\hline
\end{tabular}


$0.8 \mathrm{~m} \mathrm{~s}^{-1}$ ) are compared (using only the ignition frequencies higher than 50\%): the mean time-to-ignition is significantly higher (32.31 s) with the horizontal air flow than with the oblique one (19.49 s; Mann-Whitney test: $\mathrm{W}=-377.5$ and $\mathrm{p}=0.042$ ). The effect of air flow was not tested because of the low ignition frequencies obtained with these conditions $\left(2.5\right.$ and $\left.4.5 \mathrm{~m} \mathrm{~s}^{-1}\right)$.

The statistical tests show that the effect of firebrand type is also significant $(\mathrm{KW}=132.20 ; \mathrm{p}=0.000)$, the lowest values of time-to-ignition occurring with $P$. pinea twigs (3.92 s) and the highest ones with Pinus radiata bark (58.44 s), confirming that it is the least efficient glowing firebrand. When the tests are performed on data obtained with no air flow and flaming firebrands, the result remains the same $(\mathrm{KW}=153.64 ; \mathrm{p}=0.000)$, the highest values occurring with $P$. pinaster bark (9.10 s) and the lowest ones with Quercus ilex leaves (3.37 s).

With glowing firebrands and an air flow of $0.8 \mathrm{~m} \mathrm{~s}^{-1}$ (Table 8.b), whatever the air flow direction, the timeto-ignition generally shows a large increase compared to the results obtained with flaming firebrands (up to 77 s). Exception to this are a) Eucalyptus globulus bark on E. globulus leaf bed with an oblique air flow direction (9.1s), b) P. pinea twigs on grass bed (4.2 s) whatever the air flow direction and c) $P$. pinea cone scales on grass bed with an horizontal air flow. These types of fuel beds and firebrands have a stronger influence on the time-toignition than the air flow speed and direction. According to the statistical tests, the type of fuel bed has a significant effect on the time-to-ignition $(\mathrm{KW}=50.95 ; \mathrm{p}=0.000)$, the most flammable fuel beds are E. globulus leaves with the lowest values $(22.34 \mathrm{~s})$ and the least flammable are $P$. pinea needless $(41.13 \mathrm{~s})$. When the tests are performed on data obtained with no air flow and flaming firebrands, the result remains the same $(\mathrm{KW}=$ 79.39; $\mathrm{p}=0.000)$ but the highest values occur here with the air-dried $P$. halepensis needle bed $(6.30 \mathrm{~s})$ and the lowest ones with the dried grasses (4.58 s). Concerning the effect of fuel bed moisture content (Mann-Whitney test performed only on data presenting an ignition frequency $>50 \%$ ), the time-to-ignition values obtained with air-dried $P$. halepensis needle bed are not significantly different from the values obtained with oven-dried $P$. halepensis needle beds $(\mathrm{W}=-37 ; \mathrm{p}=0.70)$.

Statistical analysis of the ignition probability

Table 9 shows the logistic models of prediction of the ignition probability for each type of fuel bed, as a function of the type of firebrand, according to the state of the firebrand (flaming or glowing) and the air flow condition. Table 10 shows the observed ignition fraction and predicted ignition probabilities for the nine 
equations presented below. When the type of litter is not included in an equation, the showed observed ignition fraction is the average of the observed ignition fraction of each type of litter.

Table 9. Models of prediction for the ignition probability for each level of variable Pinus halepensis needle bed

Flaming firebrands $(\mathrm{n}=200)$ and no air flow

Equation $1: \log (\mathrm{Pi} / 1-\mathrm{Pi})=3.664+0.00$ FB1 + 7.17 FB2 - 3.05 FB3 - 3.46 FB4 - 1.15 FB5

Glowing firebrands $(\mathrm{n}=400)$ and $2.5 \mathrm{~m} \mathrm{~s}^{-1}$ oblique air flow

Equation $2: \log (\mathrm{Pi} / 1-\mathrm{Pi})=-\mathbf{3 . 2 5 8}+0.003 \mathrm{~W}+0.00 \mathrm{FB1}-24.68$ FB2 -0.097 FB3 -0.124 FB4

- 3.82 FB5 + 0.229 SUR - 0.637 VOL + 0.00 LIT 1 + 0.55 LIT2

Glowing firebrands $(\mathrm{n}=400)$ and $4.5 \mathrm{~m} \mathrm{~s}^{-1}$ oblique air flow

Equation $3: \log (\mathrm{Pi} / 1-\mathrm{Pi})=-1.976+0.00$ FB1 -1.30 FB2 - 0.49 FB3 + 1.13 FB4 - 22.73 FB5

+ 0.003 W+ 0.00 LIT1 + 0.958 LIT2 - 0.389 VOL

Pinus pinea needle and grass beds

Flaming firebrands $(n=480)$ and no air flow

Equation $4: \log (\mathrm{Pi} / 1-\mathrm{Pi})=0.445+0.00$ FB6 -1.361 FB7 -1.363 FB8 +0.2258 FB9 0.6352 FB10 -1.399 FB11 + 0.00 LIT3 + 0.8175 LIT4+ 0.0754 SUR

Glowing firebrands $(\mathrm{n}=480)$ and $0.8 \mathrm{~m} \mathrm{~s}^{-1}$ horizontal air flow

Equation $5: \log (\mathrm{Pi} / 1-\mathrm{Pi})=-17.00+0.00 \mathrm{FB6}+7.565$ FB7 + 8.647 FB8 + 8.227 FB9 +

9.199 FB10 + 8.386 FB11 + 0.010 VOL + 0.5684 ML

Glowing firebrands $(\mathrm{n}=480)$ and $0.8 \mathrm{~m} \mathrm{~s}^{-1}$ oblique air flow

Equation $6: \log (\mathrm{Pi} / 1-\mathrm{Pi})=-9.932$ + 0.00 LIT3 - 2.483 LIT4 + 0.00 FB6 + 0.1028 FB7 + 3.324

FB8 - 0.5021 FB9 + 2.028 FB10 + 2.491 FB11 + 0.1699 SUR + 0.8707 MF

Eucalyptus globulus leaf bed and Pinus pinaster needle bed 


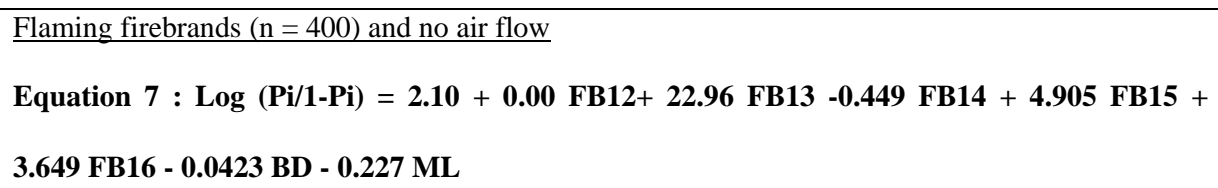

In Equation 1 (flaming firebrands and no air flow, Pinus halepensis needle bed), the only variable included in the model is the firebrand type. Quercus suber bark (FB3) and Pinus halepensis bark (FB4) have the highest negative coefficients in the equation, indicating that both firebrands have low ignition probabilities (observed ignition frequency $=$ ignition probability, $\mathrm{Pi}=0.65$ and $\mathrm{Pi}=0.55$, respectively), and would be the least flammable firebrands. Quercus ilex leaves (FB5) also have a negative coefficient, but its lower value involves a higher ignition probability (observed ignition frequency $=$ ignition probability, $\mathrm{Pi}=0.92$ ). $P$. halepensis cone scale has the highest ignition probability $(100 \%)$ that would be attributed to the higher presence of resins than in the other firebrands. Explosion of P. halepensis cone during crown fires that disperse many firebrands has been frequently observed (Leone et al., 2000). The decrease in the log likelihood was low, but the Hosmer-Lemeshow test indicates that this model has a relatively good fit. 
In Equation 2 (glowing firebrands, air flow of $2.5 \mathrm{~m} \mathrm{~s}^{-1}, P$. halepensis needle bed), the firebrand weight is the first variable included in the equation and contributes positively and moderately to the ignition probability. The ignition probability increases 1.003 times $\left(\mathrm{e}^{0.003}=1.003\right)$ for each extra gram of firebrand. This agrees with Blackmarr (1972), who found that this probability increased with the mass of ember. FB is the second variable included in the model, all the firebrand types having a low ignition probability, especially FB2 ( $P$. halepensis cone scales) and FB5 (Quercus ilex leaves). SUR contributes positively to the fit of the model, increasing the ignition probability by 1.26 times for each $\mathrm{cm}^{2}$ of extra firebrand surface. By contrast, VOL participates negatively in the equation; in this case, an increase of $1 \mathrm{~cm}^{3}$ of the firebrand volume caused a decrease of 0.47 times the ignition probability. In contrast with the experiments with no air flow, where Pinus halepensis cone scales were the particles with the highest ignition probability, here, this type of firebrand had a very low ignition probability $(\mathrm{Pi}=0-10 \%$, observed frequency $=0 \%$ ). This could be due to the small size of the glowing particles that could limit heat transfer to litter bed by conduction, whereas, with flaming firebrands, the heat transfer depends more on own flame phase than mass. Air flow cooling could also contribute to this low probability. Quercus ilex leaves showed a similar trend: high ignition probability when in flame phase and a very low ignition probability when dropped in glowing phase $(\mathrm{Pi}=1 \%$, observed frequency $=0-5 \%)$. The log likelihood decrease was low, and the value of Hosmer-Lemeshow criteria is low, suggesting that the probabilistic model does not fit adequately.

In Equation 3 (glowing firebrands, air flow of $4.5 \mathrm{~m} \mathrm{~s}^{-1}, P$. halepensis needle bed), FB (type of firebrand) is the first variable involved in the prediction model, and P. halepensis bark is the firebrand type with the highest ignition probability. Both Brand weight and LIT have a positive sign, however VOL participates with a negative sign in the equation. Pinus halepensis bark plates showed the lowest probability of ignition of the litter bed when dropped in the flaming phase without air flow (55\%) and one of highest probabilities when it fell in the glowing phase and with air flow. In both cases the probabilities of ignition were similar. The latter suggests that a compensation effect between a supplementary oxygen supply (positive) and a decreased heat transfer (by conduction) could occur. P. halepensis cone scales and Quercus ilex leaves have a low ignition probability as in the above model, independent of the air flow velocity. This model has the best fit of all those based on litter of $P$. halepensis needles.

In Equation 4 (flaming firebrands, no air flow, Pinus pinea needle bed and grass bed), the firebrand type is the first variable involved in the ignition probability. Both LIT (type of fuel bed) and SUR (firebrand surface) contribute positively but weakly to the fit of the model. Pinus halepensis cone scales are the firebrands with the 
highest ignition probability followed by Quercus ilex leaves and Pinus pinea twigs. When the litter bed was cured grasses (LIT 4) the probability of ignition was 2.26 times higher than the litter bed of P. pinea needles. This model does not have a good fit.

In Equation 5 (glowing firebrands, $0.8 \mathrm{~m} \mathrm{~s}^{-1}$ horizontal air flow, $P$. pinea needle bed and grass bed), the weight of the firebrand is the first variable included in the model, removed afterwards. The second variable is the ML (fuel moisture content of the fuel bed), with an unexpected positive relation. This could be due to the narrow range of values of this variable ( $7.2 \%$ to $13.0 \%)$. In this equation, VOL (volume of the firebrand) is positively related with the ignition probability, but its contribution is low (for each $\mathrm{cm}^{3}$ of firebrand volume, ignition probability increases 1.01 times). In these test conditions, Pinus halepensis cone also had the highest ignition probability and all the other brands had very low ignition capability. This model has an acceptable fit, with the exception of the Hosmer-Lemeshow criteria.

In Equation 6 (glowing firebrands, $0.8 \mathrm{~m} \mathrm{~s}^{-1}$ oblique air flow, $P$. pinea needle bed and grass bed), the weight of the firebrand is once more the first variable entering the prediction equation, removed afterwards. The second variable is LIT, negative in the case of LIT 4 (grasses). Change in probability of ignition as a function of different fuel beds has been described by several authors (Hargrove 2000; Lin 1999). The equation also includes FB, SUR and MF as variables. While the ratios of the ignition probability of the different types of ember were very similar to those in tests conducted with horizontal air flow, the trend was different to those observed without air flow. SUR increased the probability of ignition by 1.19 times. The values of the Hosmer-Lemeshow probability are low suggesting a poor fit.

In Equation 7 (flaming firebrands, no air flow, Pinus pinaster needle bed and Eucalyptus globulus leaf bed), the variable that most influences the ignition probability is the firebrand type which results in a great decrease in the log likelihood; Pinus radiata bark is the only firebrand that has a negative relation in the equation, and its ignition probability is the lowest. BD and ML (bulk density and fuel moisture content of the fuel bed) seem to play a minor role in the model, both acting negatively. In this case, the fit of the model can be considered fairly good in all the criteria.

In Equation 8 (glowing firebrands, $0.8 \mathrm{~m} \mathrm{~s}^{-1}$ horizontal air flow, $P$. pinaster needle bed and $E$. globulus leaf bed), the firebrand type is once more the variable with the greatest influence on the ignition probability. Eucalyptus globulus leaf (FB16) is the only firebrand that participates negatively in the equation; its ignition probability is 0 , in contrast to the high values obtained when used as a flaming brand and without air flow. The ember weight is the second variable involved in Equation 8 and it positively influences the ignition probability. 
SUR (firebrand surface) and MF (fuel moisture content of the fuel bed) only show a slight relation to ignition probability; the first one is positive and the second one negative. Other authors (Blackmarr 1972; Hargrove 2000) have found that the moisture content of different litters affect their ignition frequency. In this case, the fit of the model is slightly lower than the latter.

In Equation 9 (glowing firebrands, $0.8 \mathrm{~m} \mathrm{~s}^{-1}$ oblique air flow, P. pinaster needle bed and E. globulus leaf bed), the type of firebrand is the first selected variable. There is an appreciable reduction of the log likelihood in this step. Eucalyptus globulus leaves, $P$. pinaster cone scales and $P$. radiata bark have negative values in the equation, showing the lowest ignition probabilities, whereas Eucalyptus globulus bark has the highest ignition probability with the oblique air flow. The second variable, LIT6 (the fuel bed of Eucalyptus globulus leaves), has a negative influence on the ignition probability in contrast to $P$. pinaster needles. The needles of Pinus sp. are highly flammable in comparison with other coniferous genus (Fonda et al. 1998). They found that needles from North American pines affected by short fire return intervals were highly flammable, and this may also be the case for $P$. pinaster as well.

In the experiments with LIT5 and LIT6, three types of firebrands (Pinus pinaster cone scale, Eucalyptus globulus bark and E. globulus leaf) have high ignition probabilities ( $\geq 94 \%)$ when in the flaming phase and without air flow. Pine bark has values lower than $40 \%$. Similar results with pine scales were also obtained in the LIT1 and LIT2 experiments. This type of particles, with a high level of resin, wax and flat compounds, may result in higher flame length and, consequently, an increase in the radiation in the surrounding fuel bed. E. globulus leaves are also rich in volatile compounds and a similar effect could occur. Nevertheless, this explanation does not seem valid for the E. globulus bark which has a lower content of these compounds. During the experiments this brand showed a drastic change in its shape (flat at first and then, curved like a cylinder, keeping this latter shape when burnt on the fuel bed); this behaviour could partially explain that result. A consistent result on the experiments for all the brands is the lowering in the ignition probability when they fall in the glowing phase and with air flow, suggesting a cooling effect of the air flow, greater than the effect of increased oxygen supply. As a whole, the ignition probabilities for pine litter beds are greater than those of the Eucalyptus globulus leaves. The bulk density of the Eucalyptus fuel beds, higher than that of pine, may limit the oxygen flow on the combustion zone. Equation 9 has the best fit to the data, when all evaluation criteria are considered.

As a whole, the probability of ignition is strongly related to the firebrand type in all of the equations. In the experiments with flaming brands and without air flow, Pinus halepensis cone scales are the particles with the 
highest ignition probability (observed ignition percentage $=100 \%$ ). These particles show a very low ignition probability $(0-10 \%)$ when they drop in the glowing phase and with air flow. Several factors could bring about this result. Heat transfer by conduction from the particle to litter bed could be limited by small particle size in the second case, whereas heat transfer during flame phase (mainly by radiation and convection) could be more dependent on flame shape than on its mass. Air flow cooling could also contribute to this low probability. On the contrary, Pinus halepensis bark shows the lowest probability of ignition when they drop in the flaming phase without air flow (55\%) and one of highest probabilities when they fall in the glowing phase and with air flow. In both cases, the probabilities of ignition are similar. The latter suggests that a compensation effect between a supplementary oxygen supply (positive) and a decreased heat transfer (by conduction) could occur. In general, when embers fall in glowing phase, the ignition probability increases with the increase of their mass. This agrees with the heat transfer by conduction. Fuel bed flammability increases with air flow indicating the effect of oxygen supply. Pinus halepensis cone is the brand type which shows the highest ignition probability for all the tested conditions. In general, the cured grass bed seems to increase the ignition probability compared to the Pinus pinea litter bed, when the particles are dropped in flaming phase and no air flow. Nevertheless, the opposite occurs when the particles fall in glowing phase and with air flow.

Given that the probability of ignition is strongly related to the firebrand type and that all the firebrand types tested occur with the associated fuel beds, the worst-case should be supposed. Therefore, all the studied fuel beds show high predicted ignition probabilities (Table 10), ranging between $86 \%$ (Pinus pinea needles) and $100 \%$ (Pinus halepensis needles).

Table 10. Observed ignition fractions and predicted ignition probabilities using mean values of quantitative variables (predicted values are in parenthesis). - : no tests in these conditions.

\begin{tabular}{|c|c|c|c|c|c|}
\hline \multirow{2}{*}{\multicolumn{2}{|c|}{$\begin{array}{l}\text { Flaming firebrands and } \\
\text { no wind }\end{array}$}} & \multirow{2}{*}{\multicolumn{2}{|c|}{$\begin{array}{l}\text { Glowing firebrands and } \\
2,5 \mathrm{~m} \mathrm{~s}^{-1} \text { oblique wind }\end{array}$}} & \multicolumn{2}{|c|}{ Glowing firebrands and } \\
\hline & & & & $4,5 \mathrm{~m} \mathrm{~s}^{-1} \mathrm{o}$ & lique wind \\
\hline P.halepensis & P. halepensis & P.halepensis & P. halepensis & P. halepensis & P. halepensis \\
\hline needles & needles & needles & needles. & needles. & needles. \\
\hline $\mathrm{FMC}=3.9 \%)$ & $(\mathrm{FMC}=0 \%)$. & $(\mathrm{FMC}=3.9 \%)$ & $(\mathrm{FMC}=0 \%)$. & $(\mathrm{FMC}=3.9 \%)$ & $(\mathrm{FMC}=0 \%)$. \\
\hline
\end{tabular}




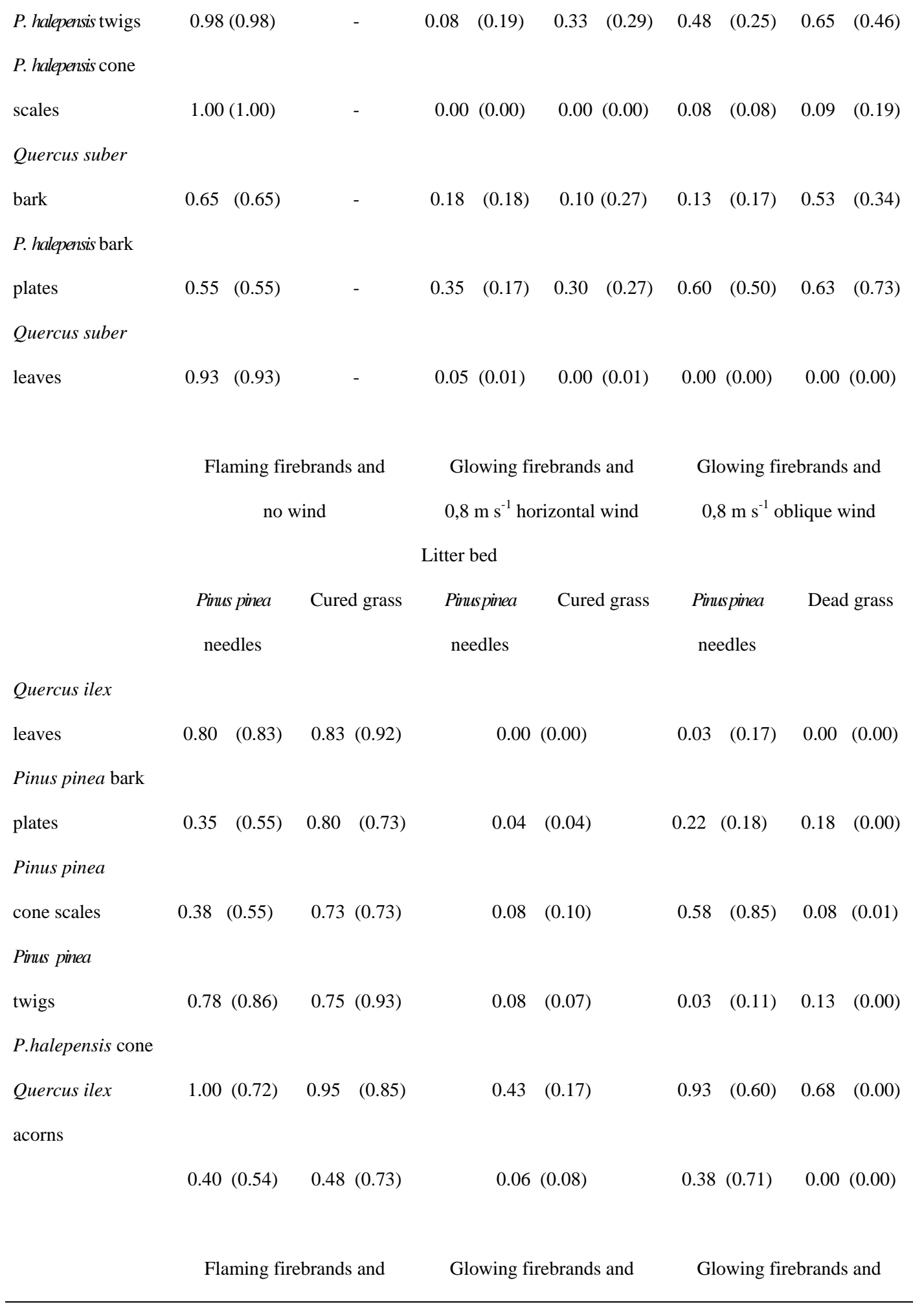




\begin{tabular}{|c|c|c|c|c|c|c|}
\hline & \multicolumn{2}{|c|}{ no wind } & \multicolumn{2}{|c|}{$0,8 \mathrm{~m} \mathrm{~s}^{-1}$ horizontal wind } & \multicolumn{2}{|c|}{$0,8 \mathrm{~m} \mathrm{~s}^{-1}$ oblique wind } \\
\hline & \multicolumn{4}{|c|}{ Litter bed } & \multirow[b]{2}{*}{ Pinus } & \multirow[b]{2}{*}{ Eucalyptus } \\
\hline & Pinus & Eucalyptus & Pinus & Eucalyptus & & \\
\hline & pinaster & globulus & pinaster & globulus & pinaster & globulus \\
\hline & needles & leaves & needles & leaves & needles & leaves \\
\hline \multicolumn{7}{|l|}{$P$. pinaster bark } \\
\hline plates & 0.38 & $(0.38)$ & 0.14 & $(0.08)$ & $0.20(0.22)$ & $0.03 \quad(0.01)$ \\
\hline \multicolumn{7}{|l|}{ P.pinaster cone } \\
\hline scales & 1.0 & $(1.00)$ & 0.04 & $(0.09)$ & $0.0 \quad(0.00)$ & $(0.00)$ \\
\hline \multicolumn{7}{|l|}{ P. radiata bark } \\
\hline plates & 0.32 & $(0.28)$ & 0.13 & $(0.08)$ & $0.03 \quad(0.02)$ & $(0.00)$ \\
\hline E. globulus bark & 0.98 & $(0.99)$ & 0.38 & $(0.43)$ & $0.83 \quad(0.89)$ & $0.20(0.23)$ \\
\hline E. globulus leaves & 0.94 & $(0.96)$ & 0.0 & $(0.00)$ & $0.03(0.00)$ & $0.00(0.00)$ \\
\hline
\end{tabular}

When the fuel bed type was not a significant variable in the logistic regression, data were pooled in one equation.

\section{Conclusions}

Concerning fuel bed flammability which we examined in terms of time-to-ignition, rate of fire spead, rate of fuel bed combustion, flame height, fuel consumption ratio and ignition frequency, the following results can be underlined:

- Grasses present a higher flammability than tree and bush litters (lower values for time-to-ignition, higher values for other parameters), even with a higher moisture content.

- Amongst litters, Pinus and Ulex europaeus litters reveal a higher flammability than hardwood litters, Eucalyptus globulus litter having intermediate characteristics.

- An increase of the fuel moisture content and of the bulk density of fuel beds implies an increase of the time to ignition and a decrease of the other parameters.

In relation to the capability of firebrands to ignite fuel beds, the experiments and the resulting models show that this capability is strongly related to the firebrand type (twig, needle, leaf, etc. of different species) or 
state (glowing or flaming) but the brand physical characteristics considered in this study do not seem to play a relevant role in the process. More research is needed to understand the influence of these other properties. Generally, the ignition caused by glowing firebrands increases with air flow, suggesting an effect due to increased oxygen supply. Amongst the studied firebrands, Pinus halepensis cone was the brand type with the highest capability of ignition for all the tested conditions. In general, firebrands have a higher probability to ignite cured grass beds than Pinus pinea needle beds, when the particles dropped in a flame phase and with no air flow. However, the opposite occurs when the particles fell in glowing phase and with air flow. The apparent absence of influence of brand weight on the process is surprising. It suggests that other properties linked to chemical composition, such as heat content or resin, wax, lipids and terpen content, could exert a decisive influence in the capability of firebrands to ignite fuel beds and should be explored in complementary experiments. Pinus halepensis bark, twig and cone as well as Eucalyptus globulus bark exhibited the highest fuel bed ignition capability when they drop in glowing phase and with air flow. In general, a consistent result for all brands was the high ignition probability observed when embers fell in flaming phase and without air flow, compared to in glowing phase and with air flow. That latter suggests a cooling effect of the air flow that is greater than the oxygen supply effect. In addition, the obtained results indicate that flaming embers falling in a short distance (without air flow) could have a high probability to cause secondary fires. This fact could be more frequent during the propagation of fire from one crown to another. Although the extrapolation from these results to the field may be problematic, these experiments showed that $P$. halepensis cones, followed by E. globulus bark are potentially the most dangerous firebrands of the studied group, under a range of different conditions. This agrees with common observations made by professionals involved in the extinction of wildfires affecting the above species, who have frequently pointed out that spotting is generally a dominant process in the propagation of fire in these types of forest.

The results presented in this paper will allow a better understanding of the fire spotting phenomenon. Nevertheless, further experiments are needed, as compared different ranges of FMC, so that it becomes a useful operational tool for prediction of ignition probability.

\section{Acknowledgements}


This research was funded by the European Commission, Directorate General XII for Science, Research and

Development, IV Environment and Climate Framework Research and Development Programme SALTUS

ENV98-CT98-0701

\section{References}

Albini FA (1979) 'Spot fire distance from burning trees: A predictive model.' USDA Forest Service, Intermountain Forest and Range Experiment Station General Technical Report INT-56. (Odgen, UT)

Albini FA (1981) 'Spot fire distance from isolated sources - Extensions of a predictive model.' USDA Forest Service, Intermountain Forest and Range Experiment Station Research Note INT-309. (Odgen, UT)

Albini FA (1983) 'Potential spotting distance from wind-driven surface fires.' USDA Forest Service, Intermountain Forest and Range Experiment Station Research Paper INT-309. (Odgen, UT)

Anderson HE (1970) Forest fuel ignitability. Fire Technology 6 (4), 312-319.

Babrauskas V (2002) 'Heat Release Rates. The SFPE Handbook of Fire Protection Engineering'. National Fire Protection Association, Quincy, MA.

Babrauskas V (2003) 'Ignition handbook’ (Fire Science Publishers: Issaquah).

Baker E (2005) 'Burning Characteristics of Individual Douglas-Fir Trees in the Wildland Urban Interface', MS Thesis, Worcester Polytechnic Institute.

Blackmarr WH (1972) 'Moisture content influences ignitability of Slash Pine litter.' USDA Forest Service South-Eastern Forest Experimental Station. Research Note, No.Se-173.

Burgan RE, Rothermel RC (1984) "BEHAVE: Fire behaviour prediction and fuel modelling system: FUEL subsystem". USDA Forest Service. Intermountain Forest and Range Experiment Station. General Technical Report INT-167. 126 p.

Delaveaud P (1981) 'Le feu, outil sylvicole? Utilisation pratique des données de combustibilité.' Mémoire de $3^{\text {ème }}$ année, ENITEF. INRA. Station de Sylviculture Méditerranéenne. Avignon.

Ellis PF (2000) 'The aerodynamic and combustion characteristics of eucalypt bark - a firebrand study -' PhD of the University of Camberra, Australia. 
Ferreira AD (1988) 'Igniçao de combustiveis finos por fosforos'. In ‘Actas das Jornadas Científicas sobre Incêndios Florestais'. 23-25 November 1988, University of Coimbra, Coimbra, Portugal.

Finney MA (1998) 'FARSITE: Fire area simulator -- model development and evaluation'. USDA Forest Service, Rocky Mountain Research Station Paper RMRS RP 4.(Ogden, UT)

.Fonda RW, Belager LA, Burley LL (1998) Burning characteristics of western conifer needles. Northwest Science 72 (1), 1-9.

Frandsen WH (1997) Ignition probability of organic soils. Canadian Journal of Forest Research 27(9), 14711477.

Gardner RH, Romme WH, Turner MG (1999) Predicting forest fire effects at landscape scales. In 'Spatial modelling of forest landscape change: approaches and applications' (Eds DJ Mladenoff, WL Baker) pp 163-185. (Cambridge University Press. Cambridge, UK)

Guijarro M, Hernando C (2000) Comportamiento del fuego en la hojarasca de Pinus pinea L. In 'Actas del 1er Simposio del pino piñonero (Pinus pinea L.)'. 22-24 February 2000. Valladolid, Spain. Vol 1, pp 263268.

Hargrove WW, Gardner RH, Turner MG, Romme WH, Despain DG (2000) Simulating fire patterns in heterogeneous landscapes. Ecological Modelling 135 (2-3), 243-236.

Hernando C (1989) 'Inflamabilidad y poder calorífico de especies del sotobosque (Zona Centro, Levante y Andalucía)', Tesis doctoral. ETSI Montes. Universidad Politécnica de Madrid.

Leone V, Sarracín A, Trabaud L, Velez R (2000) Fire prevention and management policies in west Mediterranean pine forest. In 'Ecology, Biogeography and Management of Pinus halepensis and $P$. brutia Forest Ecosystems in the Mediterranean Basin 335-353'(Backhuys Publishers, Leiden. The Netherlands)

Lin CC (1999) Modeling probatility of ignition in Taiwan red pine forests. Taiwan Journal of Forest Science 14(3):339-344

Manzello SL, Maranghides A, Mell WE, Cleary TG, Yang JC (2006a) Firebrand Production From Burning Vegetation. In 'V International Conference on Forest Fire Research'. 27-30 November 2006, Figueira da Foz, Portugal. (Ed. DX. Viegas). (University of Coimbra, Coimbra, Portugal)

Manzello SL, Cleary TG, Shields JR, Yang JC (2006b) On the ignition of fuel beds by firebrands. Fire and Materials 30, 77-87. 
Manzello SL, Cleary TG, Shields JR, Yang JC (2006c) Ignition of mulch and grasses by firebrands in wildlandurban interface fires. International Journal of Wildland Fire 15, 427-431.

Martin RE, Gordon DA, Gutierrez M, Lee D, Molina DM, Schroeder RA, Sapsis DB, Stephens S (1994) Assessing the flammability of domestic and wildland vegetation. In 'Proceedings of the 2th International Fire and Forest Meteorology Conference'. Jekyll Island, Georgia, USA, pp 130-137.

Mendes-Lopes JMC, Ventura JMP, Amaral JMP (1998) Rate of spread and flame characteristics in a bed of pine needles. In 'Proceedings of the III International Conference on Forest Fire Research-14th Conference on Fire and Forest Meteorology’, 16-20 November 1998, Luso-Coimbra, Portugal. Vol I, pp 497-511.

Plucinski MP, Anderson WR (2008) Laboratory determination of factors influencing successful point ignition in the litter layer of shrubland vegetation. International Journal of Wildland Fire 17, 628-637.

Rothermel RC (1983) 'How to predict the spread and intensity of forest and range fires.' USDA Forest Service, Intermountain Forest and Range Experiment Station General Technical Report INT-143. (Odgen, UT)

Rothermel RC, Anderson HE (1966) 'Fire spread characteristics determined in the laboratory.' USDA Forest Service, Intermountain Forest and Range Experiment Station Research Paper INT-30. (Odgen, UT)

SALTUS (2001) Fire spotting: mechanism analysis and modelling. EU Project ENV98-CT98-0701. Final report 'Probabilistic model'.

Tarifa CS, del Notario PP, Moreno FG (1965) On the flight paths and lifetimes of burning particles of wood. In 'Proceedings of the Combustion Institute' 10, 1021-1037

Tarifa CS, del Notario PP, Moreno FG (1967) Transport and combustion of fire brands. Final report of Grants FG-SP-114 and FG-SP-146, Vol 2, Instituto Nacional de Técnica Aeroespacial Esteban Terradas. (Madrid, Spain)

Trabaud L (1976) Inflammabilité et combustibilité des principales espèces des garrigues de la région méditerranéenne. Oecologia Plantarum 11 (2), 117-136.

Valette JC (1988) Inflammabilité, teneur en eau et turgescence relative de quatre espèces forestières méditerranéennes. In 'Documentos del Seminario sobre Métodos y Equipos para la Prevención de Incendios Forestales'. ICONA, MAPA. Madrid, pp 98-107.

Valette JC, Guijarro M, Maréchal J, Dupuy JL (1994) Influence of slope and fuel load on fire behaviour in pine needles fuel beds. In 'Proceedings of the 2nd International Conference on Forest Fire Research', 21-24 November 1994. Coimbra, Portugal. Vol I, pp 319-329. 
Vega JA, Cuiñas P, Bará S, Fonturbel MT, De Los Santos, JA, Rozados MJ, Alonso M, Beloso MC, Calvo E (1993) 'Forest fire prevention through prescribed burning: experimental study on fire effects on litter and soil'. Contract n ${ }^{\circ}$ CE/STEP-CT-90-0087. Final report. CIF Lourizán. Pontevedra (Unpublished).

Ventura JMP, Fernandes EC, Durao DFG (1988) Combustão de residuos florestais. Alguns resultados. In 'Actas das Jornadas Científicas sobre Incêndios Florestais’. 23-25 November 1988, University of Coimbra, Coimbra, Portugal.

Viegas DX, Neto LPC (1990) Rate of spread of a flame at varying wind conditions. In 'Proceedings of the $1^{\text {st }}$ International Conference on Forest Fire Research’. 19-22 November 1990. Coimbra, Portugal.

Viney NR, Hatton TJ (1989) Assessment of existing fine fuel moisture models applied to Eucalyptus litter. Australian Forestry 52(2), 82-93.

Waterman TE, Takata AN (1969) Laboratory study of ignition of host materials by firebrands. Project J6142OCD Work Unit 2539A, IIT Research Institute. (Chicago, IL) 